\title{
The Impact of Higher Education on Economic Growth in ASEAN-5 Countries
}

\author{
Paravee Maneejuk ${ }^{1,2, *(D)}$ and Woraphon Yamaka ${ }^{1,2}$ (D) \\ 1 Faculty of Economics, Chiang Mai University, Chiang Mai 50200, Thailand; woraphon.econ@gmail.com \\ 2 Center of Excellence in Econometrics, Chiang Mai University, Chiang Mai 50200, Thailand \\ * Correspondence: mparavee@gmail.com
}

Citation: Maneejuk, P.; Yamaka, W. The Impact of Higher Education on Economic Growth in ASEAN-5

Countries. Sustainability 2021, 13, 520 https://doi.org/10.3390/su13020520

Received: 5 December 2020

Accepted: 5 January 2021

Published: 7 January 2021

Publisher's Note: MDPI stays neutral with regard to jurisdictional clai$\mathrm{ms}$ in published maps and institutional affiliations.

Copyright: $\odot 2021$ by the authors. Licensee MDPI, Basel, Switzerland. This article is an open access article distributed under the terms and conditions of the Creative Commons Attribution (CC BY) license (https:// creativecommons.org/licenses/by/ $4.0 /)$.

\begin{abstract}
This study analyzed the nonlinear impacts of education, particularly higher education, on economic growth in the ASEAN-5 countries (i.e., Thailand, Indonesia, Malaysia, Singapore, and the Philippines) over the period 2000-2018. The impacts of education on economic growth are assessed through various education indicators, consisting of public expenditure on tertiary education per student, enrolment rates of primary, secondary, and tertiary levels, educated workforce, and the novel indicator of unemployment rates with advanced education. This study establishes nonlinear regression models-the time-series kink regression and the panel kink regression-to investigate the kink effects of education on the individual country's economic growth and the ASEAN-5 region, respectively. There are three main findings. Firstly, the nonlinear effects of the government expenditure per tertiary student on economic growth are confirmed for the ASEAN-5 region. However, the impacts do not follow the law of diminishing returns. Secondly, our findings reveal that an increase in unemployment of advanced educated workers can positively or negatively impact economic growth, which requires an appropriate policy to handle the negative impacts. Lastly, secondary and higher education enrollment rates can contribute to the ASEAN-5's economic growth (both the individual and regional levels). However, the regional analysis reveals that higher education impacts become twice as strong when the enrollment rates are greater than a certain level (a kink point). Therefore, we may conclude that secondary enrollment rates positively affect economic growth; however, higher education is the key to future growth and sustainability.
\end{abstract}

Keywords: education; higher education; economic growth; nonlinear; kink regression; ASEAN-5

\section{Introduction}

Economists have shown renewed interest in the role of human capital in economic growth in recent years. Previous studies usually consider education to be a simple measurement of human capital and attempt to examine the impacts of education on economic growth. While the education-growth linkage is widely discussed, many recent studies pay further attention to higher education levels and attempt to investigate its economic growth impact. This is because higher education is considered one of the key factors driving economic growth and competitiveness for every country. Basic education (both primary and secondary levels) may suffice for the simple production of goods and services and allows workers to use technology in the workplace. On the other hand, higher education is more likely to produce graduates that are equipped with the potential to invent new technology and that will become working persons helping transform the country into a knowledge-based economy. Higher education provides technology and innovation and delivers high-skilled workers to the labor market, thereby enhancing economic growth.

Many economists have shown evidence supporting the potential impact of higher education in both developing and developed economies (e.g., [1-3]). However, relatively few studies focus on how higher education is expanded and utilized [4,5]. According to the literature, some previous studies measure the influence of higher education through research and development (see, [6-8]). However, in this study, the relationship between 
higher education and economic growth is reinvestigated. We attempt to fill the literature gap by introducing a workforce with higher education degrees-as a proxy for highereducation expansion-in our analysis. This study also introduces a new measurement of higher-education utilization: unemployment with an advanced level of education as we believe that the contribution of higher education to the economy may relate to jobs available for the graduates. Employment is a platform where the high-skilled workers can show their potential for driving the economy to future growth. On the other hand, if there is no opportunity for those who invest in skills to get a good job, it may lead to a deadweight loss.

Besides the measurement issue, this study also highlights how education's impacts on growth are modeled. Most of the existing literature usually employs the linear model, which may be a good approximation and conform to the theories. However, the relationship between education and economic growth may be nonlinear [8]. The investigation of the nonlinear relationship between these two variables is quite limited. Only a few studies focus on nonlinearities [9-13]. One of the recent works on this issue, Maneejuk, Yamaka, and Sriboonchitta [14] points out that the linear model may overlook a significant nonlinear relationship. Therefore, in this study, the potentially nonlinear relationships will be examined by kink regression.

In the regression kink model, the regression function is continuous, but the slope has a discontinuity at a kink point. This kink point is simply a turning point, which occurs when there is a structural change in the relationship between variables. Our analysis shows that the impacts of education through several indicators may not be linear or constant over time. The impacts may increase after reaching a certain level of development or decrease due to the diminishing returns. Therefore, this study can illustrate the economic prospect resulting from the structural change after the education indicators have reached the kink point. We would need to go beyond the classical linear model to provide a new explanation of the impacts of education on economic growth under different education regimes. This study also shows whether education positively affects or discourages economic growth. To estimate this model, the ridge estimation is conducted to address the multicollinearity and sample size issues in our education-growth model. The discussion and the reasons for using the ridge estimator will be explained in the next section.

This study gives a special concern to the ASEAN-5 countries, consisting of Thailand, Indonesia, Malaysia, Singapore, and the Philippines. These five countries are considered the leading countries of the group due to the size of GDP and the relatively high economic development level. They have different cultures, lifestyles, and languages. However, the ASEAN-5 countries emphasize education in driving economic growth. Therefore, they have planned to improve the educational system and quality altogether and attempted to bring every member country's level of education into the same standard. However, the educational quality is still substantially different and unequal across countries. In the related literature, only a few studies investigated education's role, particularly of higher education, in the ASEAN-5 economies. Therefore, it could be a challenge to produce evidence on this issue and draw a conclusion on the impacts of higher education on economic growth in this area.

The major focus of this paper is to analyze the nonlinear impact of higher education on the economic growth in ASEAN-5. The main contributions of our study to the existing literature are essentially three-fold. First, this study considers the expansion of higher education along with the stock of education and investment. Second, although the impacts of higher education on economic growth have been considered, few studies use a nonlinear model to analyze this issue; while no studies have explored the kink effects of each education indicator on economic growth. Therefore, this study employs the kink regression model to investigate the kink effects of education indicators on economic growth in ASEAN5 countries, in an attempt to fill the gap in the literature. Thirdly, this is the first attempt to apply the ridge estimator to fit the kink regression model for solving the problems of data limitation and multicollinearity in our empirical model. 
The organization of this paper is as follows. After the introduction, Section 2 provides the literature review on the measurement of education and its impact on the economic growth. Then, the econometric methodology is explained in Section 3. Section 4 provides the description of the data. Section 5 shows the empirical results and discussion. Finally, Section 6 provides the conclusions and policy recommendations.

\section{Literature Review}

\subsection{Human Capital, Education, and Higher Education: A Measurement Issue}

Modern human capital theory introduced by Schultz [15] provides fundamental support for analyzing the influence of education on economic growth. Subsequently, Mincer [16] focuses primarily on labor economics and the role of human capital in the production process. The term human capital refers to the stock of skills, education, and other competencies embedded in labor. Therefore, every unit of labor hour supplied by different individuals may have a different level of efficiency depending on how much the individuals invest in their skills. However, the objective of this study is to investigate how human capital can influence the process of economic growth. One of the main theoretical approaches that explain the relationship between human capital and economic growth is the augmented Solow growth model. This model regards labor, physical capital, and human capital as inputs augmented by the total factor productivity known as the Solow residual, which drives the productivity of inputs [17]. The endogenous growth model has explicitly included human capital —as measured by education, innovation, research, and development-in the growth model (see, [18,19]). Later, Mankiw, Romer, and Weil [20] have empirically proved the augmented Solow growth model and showed that human capital could play a vital role for the long-term economic growth. It can lead to a creation of innovation and appropriate adoption of technology from abroad [21].

A possible mechanism explaining the effect of education on economic growth includes (i) the rise of productive efficiency, and (ii) the improvement of quality of the output. Note that these two mechanisms are existed due to the improved competencies following higher education levels, and consequently justifying higher labor wages [22]. Saviotti, Pyka, and Jun [23] mentioned that these two mechanisms lead to a higher purchasing power, thereby stimulating demand and growth of the production.

Even though human capital is an undoubtedly essential factor in increasing output levels and enhancing economic growth, there is still an important issue left: how human capital should be measured. Many studies in the economic growth literature have considered education as the measurement of human capital. However, the indicator for education - as a measurement of human capital—can also be separated into many aspects. Holland, Liadze, Rienzo, and Wilkinson [2] explained that measures of education can be separated into four groups: (i) stock of human capital usually measured by the average years of schooling, (ii) human capital flows proxied by school enrolment rates, (iii) investment in human capital, which is usually measured by personal and/or public expenditures on education as a share of GDP, and (iv) education system and educational quality proxied by international test scores, especially math and science [24]. Among all groups, the stock of human capital is usually considered in the empirical analysis. For example, Cohen and Soto [25] collected the data on the years of schooling and examined the impact on economic growth in OECD. This paper reveals a significantly positive impact of education on economic growth, which conforms to many studies that use years of education as a proxy (see, e.g., [1,26]). Besides, many studies also consider the school enrollment rate as a proxy of human capital flows. Starting from the influential paper of Barro [21], which studied ninety-eight countries across the world and found that economic growth is significantly related to school enrollments-as a proxy of human capital. Barro explains that higher human capital or higher school enrollment rate can bring about lower fertility rates and higher physical investment to the economy and thereby enhancing economic growth. Later, many studies have followed Barro's work and empirically proved his finding using data of many countries. For example, Wobst [27] showed a significantly positive impact of school 
enrollment on growth in Tanzania. In addition, many studies have also focused on the role of investment in education and the educational quality. For example, Keller [8] and more recently Liao, Du, Wang, and Yu [13] have considered the role of educational investment in economic growth. They examined this hypothesis in Guangdong, China and found that personal financial investment in education has a positive role in enhancing economic growth, but the magnitude of the impact can vary in different areas.

Several studies in the literature confirmed the positive impact of both stocks of education and investment in education on economic growth. However, a different education level may contribute to economic growth to a different degree. So, the further question is which education level can productively enhance economic growth. Keller [8], one of the most cited works on this issue, examined the impact of human capital flows (enrollment rates) and investment in education, each for primary, secondary, and higher education, on economic growth. Her finding reveals that enrollment rates in secondary and higher education can significantly raise economic growth, while the expenditure on education appears better allocated toward primary and secondary levels rather than higher. Many studies have attempted to re-investigate this issue. However, according to the literature, higher education appears to be one of the main factors enhancing economic performance. Volchik, Oganesyan, and Olejarz [1] examined this hypothesis in EU countries and found that higher education significantly affects economic performance of the EU countries especially during the period of globalization and digitalization. This result was confirmed by the empirical work of Habibi and Zabardast [22] who revealed that education plays a vital role in generating essential knowledge for technological progress and innovation. Hence, the high level of education could contribute to the digitalization which results in economic development. The studies of Lin [28,29] investigated the impact of education on economic growth in Taiwan from 1965 to 2000 and confirmed the important role of education on Taiwan's economic development. Holland, Liadze, Rienzo, and Wilkinson [2] also investigated the role of graduates in economic growth in the UK and found that higher education really plays an important role in the UK economy. The increase in the share of workforce with higher education degree can raise the economic growth. In addition, based on the growth accounting framework, graduates' skills can contribute to about 20 percent of the UK GDP growth during the period 1982-2005. Achim [30] also confirmed that the development of education could shift the labor productivity and responds to the labor market's needs, thereby satisfying the increased demands of the new evolving and diversifying economy.

Besides the evidence from developed countries, Gyimah-Brempong, Paddison, and Mitiku [3] investigated the impact of higher education on economic growth in Africa and found it to be positive and statistically significant in African countries. Moreover, some studies have revealed a positive relationship between higher education and growth from the world's perspective. For example, Valero and Van Reenen [5] studied the economic impact of universities in seventy-eight countries around the world and suggested that an increase in the number of universities could lead to an increase in economic growth in the future. However, they further suggested that the expenditure of universities does not directly drive economic growth. Still, the universities are likely to drive the economy by expanding knowledge and being a human capital supplier. This suggestion is in line with the argument of Holmes [4] which claimed that higher education might not necessarily lead to a higher economic growth; it depends on the expansion and the utilization of the higher education sector. Holmes [4] used the number of employed researchers in the economy as a proxy for the higher education expansion, but he failed to find a significant effect on economic growth. He explained that the undesirable results might happen due to poor data quality and measurement error problems. However, recently, many studies in the literature have paid attention to the expansion of higher education. For example, Holland et al. [2] and Volchik et al. [1] considered workforce with university degree and employment with higher education as proxies for the expansion of higher education, respectively, and analyzed the linkage between them and economic growth. 
To sum up, most of the previous studies have no doubt on the essential role of education in economic growth. Besides, many recent studies have paid attention to higher education and attempted to investigate its impact using several datasets and model specifications. On the other hand, some papers have argued that both university enrolment and higher education expenditure appear to be less important than how the higher education is expanded and utilized [4,5]. However, relatively few studies considered the impact of the expansion of higher education on economic growth. Our study considers this gap and attempts to fill it by including workforce with higher education degree-as a proxy of the higher education expansion-in our econometric analysis. This study also introduces a new measurement of the higher-education utilization: unemployment with advanced level of education. The question on how much the higher education sector can contribute to the economy also depends on how many jobs are available for the graduates. Therefore, increasing unemployment with a high-level degree is expected to produce a negative impact on the growth of the country.

\subsection{Education and Economic Growth: Modeling Issue}

In the recent decade, the existing literature has broadly discussed the relationship between education and economic growth. Many investigations have revealed that education has a potential effect on economic growth (see, e.g., [10-13]). Existing studies mainly use linear models of education's impacts on economic growth, which may be a good approximation and conform with many theoretical approaches. However, the relationship between education and economic growth may be nonlinear due to diminishing returns [8]. With respect to the linear model, Ganegodage and Rambaldi [10] used the Autoregressive Distributed Lag (ARDL) model to investigate the effect of the investment in education on Sri Lanka's economic growth during the period 1959-2008. They found a weak positive effect of the returns on investment in education on economic growth when compared to other developing countries. Likewise, using the same model, Merca and Sezer [11] studied the impact of education expenditure on the economic growth of Turkey and found that education expenses contribute a positive and significant effect to economic growth. Jin, and Jin [12] applied the linear regression model to investigate the effects of Internet education on economic growth using a cross-section of 36 high-income countries. They indicated that the frequent usage of internet education could promote economic growth.

On the contrary, Zhu [31] employed the panel regression to verify the effect of various education factors on the economic growth of China's 30 provinces from 2000 to 2010. He found that special education graduates, primary school graduates, high school graduates and junior middle-school graduates have no significant impact on economic growth. Abu, Haseeb and Azam [32] and Liao et al. [13] attempted to find the causal relationship between education and economic growth in China and Malaysia, respectively, using cointegration and causality methods. The results showed a bidirectional causality between these two variables. Interestingly, Liao et al. [13] revealed that the bi-directional relationship between these two variables has occurred only in the short run, but there is unidirectional causality of educational investment on Chinese economic growth in the long run. This evidence has also been found in the work of Sylweste [33] which revealed that education spending harms economic growth in the short term, but it plays a positive role in the long run.

According to the above literature review, the inconclusive impact of education on economic growth is found. Many studies indicated that education has a positive impact on economic growth, some studies argued that there is no significant contribution of education to economic growth, and other studies mentioned that there are heterogeneous effects in the short run and long run. Since previous research works did not reach a consistent conclusion, we doubt that the impact of education on economic growth may be nonlinear. The linear specification may oversimplify the education-growth nexus when the nonlinear link between dependent and independent variables exists. Generally speaking, the impact of education on economic growth may not be fixed over time. Considering this fact, some studies began to examine the nonlinear mechanism between education and 
economic growth. The nonlinear education-growth nexus was first examined by Krueger and Lindahl [34]. They divided their sample of countries into three subsamples based on their initial human capital endowment, and heterogeneous results were obtained. They found that education contributed a positive and a negative effect to economic growth in the subsample of countries with the lowest and highest educational levels, respectively. For the group of countries in the middle of the education level, they found that some education factors have a negative effect on economic growth, while other factors have no effect on growth. Jalil and Idrees [35] investigated the impact of education on the economic growth of Pakistan. They collected the data over the period from 1960 to 2010 and used the nonlinear regression model (estimated by the nonlinear two-stage least-square method) to fit these data. They pointed out that different levels of education contribute to the different magnitude of positive effects on the economic growth in Pakistan. Recently, Marquez-Ramos and Mourelle [36] tested the existence of a nonlinear relationship between education and economic growth of Spain using the smooth transition regression model. They considered enrolment ratio in secondary education and enrolment ratio in tertiary education as the threshold variables. They revealed a negative and significant effect of the enrolment ratio of tertiary education on economic growth in two regimes: when enrolment ratio tertiary education is greater or less than $5.2 \%$.

This analysis enables us to shed light on the question posed by the existing literature about the nonlinear impact of education on economic growth. Consequently, based on the empirical results, this study innovates by using kink regression [37] to investigate the kink or nonlinear effects of education on economic growth in ASEAN-5. The advantages of the kink regression over the traditional nonlinear models (threshold regression, smooth transition regression, and Markov-switching regression models) include that it allows us to contain both linear and nonlinear effects of explanatory variables in the outcome variable. In addition, it is unlike the threshold and smooth transition regression models, which use only one threshold variable to determine the structural change of the model. We suspect that one threshold variable may be inadequate to describe the nonlinear effect causing the regime change. It would be more convincing if all explanatory variables can be threshold variables, thereby having their own kink points $[14,38,39]$. Therefore, the kink regression, which allows each independent variable to switch between the regimes, is employed in this empirical study.

In our empirical analysis, we incorporate several education variables as well as control variables that are related to economic growth. However, we are concerned that these explanatory variables may be highly correlated and lead to the multicollinearity problem. Several studies have mentioned the relationship between education factors. For example, Chen and $\mathrm{Wu}$ [40] provided evidence that the development of education is beneficial to the decrease in the unemployment rate. Abdullah [41] highlighted the relationship between secondary and tertiary education in Malaysian datasets. Birchler and Michaelowa [42] emphasized the relationship between primary and secondary education aids and education enrolment.

Due to the multicollinearity problem in the existing literature, the correlated education factors, as well as correlated control variables, cannot be considered jointly in the growth model. Thus, many scholars suggested removing one or more of these correlated explanatory variables to solve this problem. However, if the dropped variables are relevant to the economic growth, the traditional least-squares kink regression can produce biased and inconsistent estimates, which accounts for the name omitted variable bias. Mason and Brown [43] mentioned that the omitted variable bias could produce severe difficulties in subsequent theoretical interpretation of social science data. In this study, both omitted variable bias and multicollinearity problems are the matters of concern; we thus suggest the ridge estimation of Hoerl and Kennard [44] to fit the kink regression model. When multicollinearity occurs, least-squares estimation is unbiased, but their variances are large and thereby generate the higher variance in the parameter estimates. By adding a degree of bias to the regression estimates, the ridge estimator could decrease the standard errors of 
the coefficients [45]. Perez Melo and Kibria [46] compared the performance of least-squares and ridge estimations and revealed that mean square error (MSE) for the ridge estimator is lower than the variance of the least-squares. Another advantage of the ridge estimator is that it still performs well in a situation where the number of explanatory variables is larger than the number of observations. Consequently, the limitation of our ASEAN-5 education and economic data is not a severe problem in our study.

To the best of our knowledge, most studies are based on linear regression analysis, while few studies emphasize the nonlinear structure as well as country difference. Another point is the negligence of the problems brought about by the omitted variable bias and multicollinearity. Generally speaking, the model could suffer from omitted variable bias if we omit relevant independent variables from the model. However, if the additional explanatory variable is correlated with other explanatory variables, the model would suffer from multicollinearity. So, which one is more important? It can sometimes be challenging to deal with both omitted variable bias and multicollinearity problems. Moreover, using the classical least-squares method without data inspection can lead to unreliable results. Thus, we also contribute to the methodology literature by extending the ridge regression estimator to ridge kink regression.

\section{Methodology}

\subsection{Kink Regression}

Our two-regime kink regression model takes the form:

$Y_{t}=\beta_{1}^{-}\left(x_{1, t}-\gamma_{1}\right)_{-}+\beta_{1}^{+}\left(x_{1, t}-\gamma_{1}\right)_{+}+, \ldots,+\beta_{K}^{-}\left(x_{K, t}-\gamma_{K}\right)_{-}+\beta_{K}^{+}\left(x_{K, t}-\gamma_{K}\right)_{+}+\alpha Z_{t}+\varepsilon_{t}$

where $Y_{t}$ is the continuous dependent variable at time $t, x_{k, t}$ is the continuous independent variable $k$ at time $t$, and $Z_{t}$ denotes the $(1 \times Q)$ vector of the regime independent exogenous variables at time $t$. The linear relationship appears between $Y_{t}$ and $Z_{t}$ while the relationship between $Y_{t}$ and $x_{k, t}$ is nonlinear, due to the relationship of $Y_{t}$ and $x_{k, t}$ changes at the unknown location called the threshold or the kink point $\gamma_{k}$. However, the kink regression model is continuous in the variables $x_{k, t}$ and $Z_{t}$, but the slope with respect to $x_{k, t}$ is discontinuous at the threshold or kink point $\gamma_{K}$. Then, $\beta$ is a matrix of $(T \times K \times 2)$ coefficients of unknown parameters and consist of $\left(\beta_{1}^{-}, \ldots, \beta_{K}^{-}\right)$and $\left(\beta_{1}^{+}, \ldots, \beta_{K}^{+}\right)$with respect to variable $x_{k, t}^{\prime}$ for the values of $x_{k, t}^{\prime} \leq \gamma_{k}$ and $x_{k, t}^{\prime}>\gamma_{k}$, respectively. According to Hansen [37], the regressor variables are subject to regime-change at the kink point $\left(\gamma_{1}, \ldots, \gamma_{K}\right)$ thus, these regressors can be separated into two regimes. $\alpha$ is the $(Q \times 1)$ vector of linear parameters. $\varepsilon_{t}$ is the error term at time $t$ with normal distribution and $E\left(\varepsilon_{t}\right)=0$. Traditionally, the least-square estimation is used to estimate $\beta=\left(\beta_{0}, \beta_{1}^{-}, \ldots, \beta_{K}^{-}, \beta_{1}^{+}, \ldots, \beta_{K}^{+}, \alpha\right)$ and $\gamma=\left(\gamma_{1}, \ldots, \gamma_{K}\right)$, and the estimation is given by

$$
S_{T}(\boldsymbol{\beta}, \boldsymbol{\gamma})=\frac{1}{T} \sum_{t=1}^{T}\left(Y_{t}-\boldsymbol{\beta}^{\prime} \mathbf{X}_{t}(\gamma)\right)^{2}
$$

where

$$
\mathbf{X}_{t}(\gamma)=\left[\begin{array}{c}
\left(x_{1, t}-\gamma_{1}\right)_{-} \\
\vdots \\
\left(x_{K, t}-\gamma_{K}\right)_{-} \\
\left(x_{1, t}-\gamma_{K}\right)_{+} \\
\vdots \\
\left(x_{K, t}-\gamma_{K}\right)_{+} \\
Z
\end{array}\right]
$$

The least-square estimators $\widehat{\beta}, \widehat{\gamma}$ are the joint minimizer of $S_{T}(\boldsymbol{\beta}, \boldsymbol{\gamma})$ :

$$
(\widehat{\boldsymbol{\beta}}, \widehat{\gamma})=\underset{\beta, \gamma}{\operatorname{argmin}}\left(S_{T}(\boldsymbol{\beta}, \boldsymbol{\gamma})\right)
$$




\subsection{Ridge Kink Regression Estimator}

As the least square is not applicable when the regressor variables are highly correlated and large in number, the ridge estimator is applied to fit the kink regression. According to Hoerl and Kennard [44], they proposed the ridge, which minimizes the residual sum of squares under a constraint on the $\ell^{2}-$ norm of the coefficient vector. We then apply this estimator to estimate the kink regression model and the estimator of $\beta$ and $\gamma$ in the model (1) takes the form

$$
S_{T}(\boldsymbol{\beta}, \boldsymbol{\gamma}, \lambda)=\frac{1}{T} \sum_{t=1}^{T}\left(Y_{t}-\boldsymbol{\beta}^{\prime} \mathbf{X}_{t}(\boldsymbol{\gamma})\right)^{2}+\lambda \sum \boldsymbol{\beta}^{2}
$$

and $\lambda \geq 0$ is a non-negative regularization parameter. The additional term $\lambda \sum \beta^{2}$ is the ridge penalty function, which shrinks kink regression coefficients towards zero as $\lambda$ increases. In the view of Equation (5), we penalize only $\beta$ and opt not to penalize $\gamma$ since it is worth nothing when $\gamma$ is shrunk to zero. It is important to note that $\lambda \rightarrow \infty$ ridge penalty function approaches infinity and yields an empty ridge estimation whereas when $\lambda \rightarrow 0$, the ridge penalty function approaches zero, and the ridge kink regression estimator is reduced to least-square regression estimator (Equation (2)). The role of the regularization parameter $\lambda$ is essential in the estimation process. However, the loss function (Equation (4)) is quadratic in $\beta$ but nonconvex in $\lambda$. Thus, it is computationally convenient to view this parameter as the tuning parameter for controlling the overall penalty level, and in this study, we consider the extended Bayesian information criterion (EBIC) to find the optimal ridge parameters for our estimation.

Similar to the least-square estimator, given the candidate $\tilde{\lambda}$, ridge kink regression estimator $(\widetilde{\boldsymbol{\beta}}, \widehat{\gamma}, \lambda)$ is the joint minimizer of $S_{n}(\boldsymbol{\beta}, \boldsymbol{\gamma}, \widetilde{\lambda})$ :

$$
(\tilde{\boldsymbol{\beta}}, \tilde{\gamma}, \tilde{\lambda})=\underset{\boldsymbol{\beta} \in R^{P}, \boldsymbol{\gamma} \in \Gamma}{\operatorname{argmin}} S_{n}(\boldsymbol{\beta}, \boldsymbol{\gamma}, \tilde{\lambda})
$$

Then, the optimal $\tilde{\lambda}$ can be easily determined by minimization of the concentrated sum of the squared errors Equation (5). In other words, the optimal $\widehat{\lambda}$ is obtained at the lowest EBIC. Once the optimal $\widehat{\lambda}$ is defined, we can estimate $\widehat{\beta}$ and $\widehat{\gamma}$ using standard penalized least-squares of $Y_{t}$ on $\mathbf{X}_{t}(\widehat{\gamma})$ with the additional penalty function $\widehat{\lambda} \sum \boldsymbol{\beta}^{2}$.

\subsection{Testing for the Time Series Kink Effect}

As the nonlinear relationship between education and economic growth is considered in this study, it is crucial to examine the kink effect. Additionally, it is vital to learn which independent variable has a nonlinear impact on economic growth. Hence, we firstly define a test of no kink effect against the presence of kink effect for each pair of dependent variables and the covariate $k$. That is, the null and alternative hypotheses for each covariate $k$ are that

$$
\begin{aligned}
& H_{0}: \beta_{k}^{-}=\beta_{k}^{+} \\
& H_{a}: \beta_{k}^{-} \neq \beta_{k}^{+} .
\end{aligned}
$$

To test this hypothesis, Hansen [37] recommended using the F-test:

$$
F_{k}^{*}=\frac{\left(S S E_{0}^{k}-S S E_{1}^{k}(\widehat{\gamma})\right)}{S S E_{1}^{k}(\widehat{\gamma}) /(T-1)}
$$

where

$$
S S E_{0}^{k}=\sum_{t=1}^{T}\left(Y_{t}-\hat{\beta}_{k} x_{k, t}\right)^{2}
$$




$$
S S E_{1}^{k}=\sum_{t=1}^{T}\left(Y_{t}-\widehat{\beta}_{k}^{-}\left(x_{k, t}-\widehat{\gamma}_{k}\right)_{-}-\widehat{\beta}_{k}^{+}\left(x_{k, t}-\widehat{\gamma}_{k}\right)_{+}\right)
$$

Hansen [37] mentioned that this F-test might not have a standard distribution; thus, he suggested using the bootstrap method to generate asymptotically first-order corrected $p$-values. Zhang and Cheng [47] mentioned that the $p$-value yielded from the bootstrap could be employed to validate the existence of a nonlinear relationship. Thus, in this study, we follow the traditional criteria; the null hypothesis of the kink effect is rejected if the $p$-value is less than the desired critical value, e.g., $0.10,0.05$, and 0.01 .

\section{Data}

This section introduces the data used in our analysis and provides a brief description of each variable and the sources of the data. We use time-series and panel data of ASEAN-5 countries, namely Thailand, Indonesia, Malaysia, Singapore, and the Philippines. The data cover the period of 2000-2018 as many variables are available for this period while the data after the year 2019 have not been updated yet. Economic growth measured by GDP per capita is the dependent variable perceived to be influenced by six education indicators and the control variables. This study considers primary, secondary, and university enrollment rates, education expenditure per student in the tertiary level, and the expansion of higher education measured by the workforce with high degree and the share of unemployment of high-skilled workers. Furthermore, the five control variables considered are trade openness, foreign direct investment (FDI), research and development, inflation rate, and capital stocks. Description of the variables is presented in Table 1.

Table 1. Variable description.

\begin{tabular}{|c|c|c|c|}
\hline Variable & Variable & Description & Source \\
\hline $\begin{array}{l}\text { Dependent } \\
\text { variable }\end{array}$ & GDP & Real GDP per capita & CEIC \\
\hline \multirow{3}{*}{$\begin{array}{l}\text { Education } \\
\text { variable }\end{array}$} & EXPSTU & $\begin{array}{c}\text { Education expenditure per student refers to the average annual goverment } \\
\text { expenditure per student in the tertiary level. It is calculated by dividing the } \\
\text { total government expenditure on tertiary education by the number of } \\
\text { students at the tertiry level (unit: US dollar) }\end{array}$ & \multirow{3}{*}{$\begin{array}{l}\text { National Statistical } \\
\text { Office of Thailand; } \\
\text { Department of } \\
\text { statistics Singapore; } \\
\text { Department of } \\
\text { statistics Malaysia; } \\
\text { Philippines Statistics } \\
\text { Authority; the Central } \\
\text { Bureau of Statistics, } \\
\text { Indonesia; and } \\
\text { International Labour } \\
\text { Organization }\end{array}$} \\
\hline & $\begin{array}{l}\text { Primary } \\
\text { Secondary } \\
\text { Tertiary }\end{array}$ & $\begin{array}{l}\text { Primary, Secondary, and Tertiary stand for the enrollment rate of primary, } \\
\text { secondary, and tertiary levels, respectively. The enrollment rate is measured } \\
\text { by the ratio of total enrollment to the population having the age officially } \\
\text { corresponds to the level of education (unit: \% gross). }\end{array}$ & \\
\hline & WORK & $\begin{array}{l}\text { Workforce with education refers to the working-age population with a } \\
\text { higher level of education (or university degree) who are in the labor force, } \\
\text { that is, the number of a highly educated workforce (unit: thousand persons). }\end{array}$ & \\
\hline
\end{tabular}

Unemployment with higher education refers to the labor force with an advanced level of education who are unemployed. Advanced education

UNEM consists of bachelor's degree, master's degree, and doctoral degree (unit: \%

World Bank of total unemployment).

\begin{tabular}{ccc} 
OPEN & $\begin{array}{c}\text { Trade openness measures how much a country is engaged in the world trade. } \\
\text { It is measured by the ratio of the sum of exports and imports to GDP (unit: } \\
\text { times of GDP). }\end{array}$ \\
\cline { 2 - 3 } $\begin{array}{c}\text { Control } \\
\text { variable }\end{array}$ & FDI & $\begin{array}{c}\text { Research and Development expenditure refers to gross domestic expenditure } \\
\text { on research and development of, for example, business, non-profit } \\
\text { organization, government, and education sector (unit: \% of GDP). }\end{array}$ \\
\cline { 2 - 4 } & INF & $\begin{array}{c}\text { Inflation rate (unit: \%). } \\
\text { Capital stock refers to the net capital stock, the market value of total fixed } \\
\text { assets in the economy, reflecting the country's overall wealth (unit: thousand } \\
\text { US dollars). }\end{array}$ \\
\hline
\end{tabular}

Note: CEIC is the is the global economic database. Available online: https:/ / www.ceicdata.com. 
A brief statistical description of the variables is provided in Table A1, Appendix A. According to this table, we can highlight several characteristics of our variables. All the education variables present a positive mean value from 2000 to 2018 for all countries. The mean of the logarithm of real GDP per capita is positive across countries and ranges from the lowest of 8.677 for the Philippines to the highest of 11.490 for Singapore. In terms of education expenditure per tertiary student (lnEXPSTU), Singapore has the highest while the Philippines has the lowest. Comparing the enrollment rates, we observe that primary education has the highest enrollment rate, followed by secondary and tertiary education, respectively, for all countries, except for Singapore where the level of secondary education shows the highest average enrollment rate compared to the primary and the tertiary education.

Furthermore, Thailand is among the highest in terms of working-age population with a higher level of education (lnWORK), with an average of 10.521, while Singapore has the lowest average of $\operatorname{lnWORK}$ (6.216). Thailand is also among the lowest for the labor force with an advanced level of education who are unemployed (lnUNEM) with an average of 0.102, while the Philippines shows the highest average of lnUNEM (2.335). For the control variables, the mean values of control variables across countries are mostly positive in our sample, except for research and development (RD). We find that the average of the logarithm of research and development is negative for Thailand, Malaysia, Indonesia, and the Philippines, indicating that these four countries have a low percentage of research and development expenditure in their GDP.

It is important to note that the log transformation of our variables may be suitable for direct estimation. Nevertheless, the spurious relationship or pseudo regression may occur due to the nonstationarity problem in our time series. Thus, before focusing on the impact of education on economic growth, we need to test the stationarity of our data. By doing this, we use the Augmented Dickey-Fuller (ADF) test. The test results are also presented in Table A1, Appendix A, revealing that all variables are nonstationary at the level and stationary at first difference. This means the spurious relation may exist in the case of our empirical study. However, this study aims to save the number of observations and keep the logarithm transformation. We, then, still proceed with our study using these nonstationary data. Once the model is estimated, we will use the cointegration test of Engle and Granger [48] to confirm the long-term relationship between the dependent variable and independent variables in our model. If the long-term relationship is confirmed by the cointegration test, our regression model becomes non-spurious.

As our empirical model contains various independent variables, it is worth investigating the collinearity among the independent variables to test the multicollinearity problem. This problem occurs when a linear relationship exists between two or more of the independent variables. The problem leads to unreliable parameter estimates and large standard errors. Radu [49] suggested that the cause of the multicollinearity problem is usually the limitation of the data rather than the specification of the model. In this study, we also have a concern over this problem because the data available for analyzing the ASEAN- 5 counties are not in the same form and are missing in some variables.

The correlation matrices of all independent variables are shown in Tables A4-A7, Appendix A. To simplify the results, we highlight the strength of the correlation in color for the absolute values of the correlation ranging between 0 and 0.30 (green), between 0.31 and 0.80 (yellow), and between 0.81 and 1.0 (orange) which indicate the weak, moderate, and strong correlation, respectively. Tables A4-A7 reveals the existence of a strong correlation (larger than 0.80 ), a rule of thumb [12] in many pairs of independent variables (orange color) for all countries, indicating that our model may encounter the multicollinearity problem. However, as the ridge estimator is employed to estimate the kink regression, we, therefore, claim that the multicollinearity problem may not be serious in our empirical model. 


\section{Empirical Results and Discussion}

\subsection{Results of the Kink Effect Test}

The kink parameters could govern the nonlinear relationship between the dependent and each independent variable. Thus, in this section, we conduct the kink test of Hansen [37] for testing the existence of the kink effect between each independent variable and the dependent variable. That is, the kink effect on the relationship between the dependent variable and its covariate is examined as a single equation. Table 2 presents the test results for five empirical models (Thailand, Singapore, Malaysia, Indonesia, and the Philippines). The kink effect tests for education variables are presented in rows 2 to 6 , while rows 8 to 12 present the kink tests for the control variables. The F-test statistics and their $p$-values are reported and summarized, as in the following presentation. (1) The null hypothesis of no kink effect is rejected in lnEXPSTU, lnWORK, how much a country is engaged in the world trade (lnOPEN), lnFDI, and inflation rate (INF) for all countries using the $10 \%$ significance level as the critical level, indicating a linear impact of these variables on the economic growth of all ASEAN-5 countries. (2) The alternative hypothesis of the kink effect is accepted for four education variables: lnPrimary, lnSecondary, lnTertiary, and lnUNEM and two control variables: $\operatorname{lnRD}$ and caital wealth $(\operatorname{lnK})$ in some countries. Specifically, lnPrimary is found to have a nonlinear effect only for the case of Thailand. InSecondary is found to have a nonlinear impact in Thailand, Indonesia, and the Philippines, lnTertiary presents kink effects on Thailand, Singapore, and Indonesia, while lnUNEM shows the kink effects on economic growth for all countries. Moreover, two control variables have a significant kink effect on growth. lnRD shows a statistically significant kink effect on Thai economic growth, while $\operatorname{lnK}$ has a significant nonlinear impact on the economic growth of Thailand, Indonesia, and the Philippines. According to these results, we can observe the kink effects of education factors on economic growth of ASEAN- 5 countries, whereas Thailand displays a decisive nonlinear impact as four out of the six education variables have a statistically significant kink effect. In contrast, the weakest nonlinear impact of education is found in Malaysia.

Table 2. Kink effect test: $F_{k}^{*}$.

\begin{tabular}{ccccccc}
\hline Country & lnEXPSTU & lnPrimary & lnSecondary & lnTertiary & lnUNEM & lnWORK \\
\hline \multirow{2}{*}{ Thailand } & 1.783 & $\mathbf{8 . 5 4 0}$ & $\mathbf{9 . 3 6 8}$ & $\mathbf{1 9 . 4 9 6}$ & $\mathbf{1 3 . 2 5 3}$ & 7.2680 \\
& $(0.491)$ & $\mathbf{( 0 . 0 3 1 )}$ & $\mathbf{( 0 . 0 2 1 )}$ & $\mathbf{( 0 . 0 0 0 )}$ & $\mathbf{( 0 . 0 0 0 )}$ & $(0.110)$ \\
Singapore & 4.402 & 0.825 & 1.614 & $\mathbf{1 2 . 8 8 6}$ & $\mathbf{8 . 6 2 3}$ & 1.012 \\
& $(0.766)$ & $(0.994)$ & $(0.584)$ & $\mathbf{( 0 . 0 0 0 )}$ & $\mathbf{( 0 . 0 2 1 )}$ & $(0.854)$ \\
Malaysia & 10.043 & 10.354 & 6.578 & 6.610 & $\mathbf{1 5 . 7 0 2}$ & 2.886 \\
& $(0.541)$ & $(0.515)$ & $(0.744)$ & $(0.761)$ & $\mathbf{( 0 . 0 5 1 )}$ & $(1.000)$ \\
Indonesia & 10.517 & 5.861 & $\mathbf{2 2 . 4 9 7}$ & $\mathbf{2 7 . 4 9 4}$ & $\mathbf{2 6 . 9 6 4}$ & 5.548 \\
& $(0.261)$ & $(0.755)$ & $\mathbf{( 0 . 0 2 1 )}$ & $\mathbf{( 0 . 0 0 0 )}$ & $\mathbf{( 0 . 0 0 0 )}$ & $(0.767)$ \\
Philippines & 0.942 & 3.664 & $\mathbf{1 2 . 1 3 9}$ & 5.709 & $\mathbf{1 5 . 3 4 8}$ & 6.333 \\
& $(0.961)$ & $(0.641)$ & $\mathbf{( 0 . 0 2 3 )}$ & $(0.343)$ & $\mathbf{( 0 . 0 0 0 )}$ & $(0.294)$ \\
\hline \multirow{2}{*}{ Thailand } & $\operatorname{lnOPEN}$ & $\ln \mathrm{FDI}$ & $\ln \mathrm{RD}$ & $\mathrm{INF}$ & $\ln \mathrm{C}$ & \\
& 1.598 & 0.144 & $\mathbf{6 . 4 2 3}$ & 1.378 & $\mathbf{2 1 . 0 3 3}$ & \\
Singapore & $0.231)$ & $(0.911)$ & $\mathbf{( 0 . 0 5 1 )}$ & $(0.522)$ & $\mathbf{( 0 . 0 0 0 )}$ & \\
& 0.912 & 0.386 & 0.511 & 0.645 & 1.458 & \\
Malaysia & $(0.999)$ & $(1.000)$ & $(1.000)$ & $(1.000)$ & $(0.601)$ & \\
& 4.027 & 6.397 & 9.949 & 7.587 & 12.511 & \\
Indonesia & $(0.866))$ & $(0.735)$ & $(0.573)$ & $(0.675)$ & $(0.361)$ & \\
& 3.762 & 7.221 & 10.588 & 6.492 & $\mathbf{2 9 . 7 3 9}$ & \\
Philippines & $(0.843)$ & $(0.643)$ & $(0.253)$ & $(0.658)$ & $\mathbf{( 0 . 0 0 0 )}$ & \\
& 7.679 & 8.020 & 7.261 & 4.133 & $\mathbf{1 9 . 3 7 9}$ & \\
\hline No. & $(0.197)$ & $(0.140)$ & $(0.211)$ & $(0.487)$ & $\mathbf{( 0 . 0 0 0 )}$ &
\end{tabular}

Note: The values in parentheses () are the $p$-values. A bold number indicates a significant kink effect. 


\subsection{Main Results of Kink Ridge Kink Regression}

After testing the presence of the kink effect, the next step is to build the kink regression model for each country and estimate the regressors and their corresponding kink parameters. However, to ensure the reliability of our kink model, we compare this type of model with the ridge linear regression model, as presented in Table 3. The EBIC is used to achieve our comparison. The EBIC values of linear regression and kink regression models are reported in the last row of Tables 3 and 4, respectively. It is found that our kink models outperform the linear model for all countries, implying that the kink regression is appropriate for this analysis, that is, the nonlinear impacts of education on the economic growth of all five ASEAN countries.

Table 3. Ridge linear regression results for all five countries.

\begin{tabular}{|c|c|c|c|c|c|}
\hline Variable & Thailand & Singapore & Malaysia & Indonesia & Philippines \\
\hline \multicolumn{6}{|c|}{ Estimate } \\
\hline intercept & $\begin{array}{c}1.872^{* * *} \\
(0.125)\end{array}$ & $\begin{array}{l}4.713^{* * *} \\
(1.202)\end{array}$ & $\begin{array}{c}3.451^{* * *} \\
(1.311)\end{array}$ & $\begin{array}{c}10.370^{* * *} \\
(2.112)\end{array}$ & $\begin{array}{l}8.544^{* * *} \\
(2.184)\end{array}$ \\
\hline $\operatorname{lnEXPSTU}$ & $\begin{array}{c}0.150 * * * \\
(0.036)\end{array}$ & $\begin{array}{c}0.059 \\
(0.042)\end{array}$ & $\begin{array}{c}0.090^{* * *} \\
(0.026)\end{array}$ & $\begin{array}{c}0.033 \\
(0.057)\end{array}$ & $\begin{array}{l}0.107^{* *} \\
(0.044)\end{array}$ \\
\hline lnPrimary & $\begin{array}{l}-0.023 \\
(0.035)\end{array}$ & $\begin{array}{c}0.065 \\
(0.052)\end{array}$ & $\begin{array}{c}0.129^{* * *} \\
(0.035)\end{array}$ & $\begin{array}{l}-0.061 \\
(0.045)\end{array}$ & $\begin{array}{c}-0.091 \text { *** } \\
(0.031)\end{array}$ \\
\hline lnSecondary & $\begin{array}{l}0.179^{* * *} \\
(0.042)\end{array}$ & $\begin{array}{l}0.078 \text { ** } \\
(0.038)\end{array}$ & $\begin{array}{c}0.029 \\
(0.026)\end{array}$ & $\begin{array}{c}0.280 * * * \\
(0.064)\end{array}$ & $\begin{array}{c}0.179 * * * \\
(0.036)\end{array}$ \\
\hline lnTertiary & $\begin{array}{l}0.036^{*} \\
(0.019)\end{array}$ & $\begin{array}{l}0.115^{* *} \\
(0.047)\end{array}$ & $\begin{array}{l}0.079 * * \\
(0.034)\end{array}$ & $\begin{array}{c}0.175^{* * *} \\
(0.059)\end{array}$ & $\begin{array}{l}0.091 \text { ** } \\
(0.042)\end{array}$ \\
\hline $\operatorname{lnUNEM}$ & $\begin{array}{l}0.191^{* * * *} \\
(0.039)\end{array}$ & $\begin{array}{l}-0.039 \\
(0.049)\end{array}$ & $\begin{array}{c}0.179 * * * \\
(0.028)\end{array}$ & $\begin{array}{l}-0.102 \\
(0.064)\end{array}$ & $\begin{array}{c}-0.2007^{* * * *} \\
(0.034)\end{array}$ \\
\hline $\operatorname{lnWORK}$ & $\begin{array}{c}0.180^{* * *} \\
(0.035)\end{array}$ & $\begin{array}{c}0.246^{* * *} \\
(0.052)\end{array}$ & $\begin{array}{l}0.078^{* *} \\
(0.035)\end{array}$ & $\begin{array}{l}0.088^{*} \\
(0.049)\end{array}$ & $\begin{array}{l}-0.006 \\
(0.023)\end{array}$ \\
\hline $\operatorname{lnOPEN}$ & $\begin{array}{c}-0.060^{* * *} \\
(0.022)\end{array}$ & $\begin{array}{l}-0.013 \\
(0.057)\end{array}$ & $\begin{array}{l}-0.043 \\
(0.036)\end{array}$ & $\begin{array}{l}-0.101 \\
(0.068)\end{array}$ & $\begin{array}{l}-0.024 \\
(0.415)\end{array}$ \\
\hline $\operatorname{lnFDI}$ & $\begin{array}{c}0.027 \\
(0.018)\end{array}$ & $\begin{array}{l}0.103^{* *} \\
(0.040)\end{array}$ & $\begin{array}{c}0.014 \\
(0.021)\end{array}$ & $\begin{array}{c}0.011 \\
(0.042)\end{array}$ & $\begin{array}{c}0.024 \\
(0.031)\end{array}$ \\
\hline $\ln R D$ & $\begin{array}{l}0.090^{* *} \\
(0.038)\end{array}$ & $\begin{array}{c}0.032 \\
(0.039)\end{array}$ & $\begin{array}{c}0.134^{* * *} \\
(0.032)\end{array}$ & $\begin{array}{c}0.051 \\
(0.041)\end{array}$ & $\begin{array}{c}0.218^{* * *} \\
(0.036)\end{array}$ \\
\hline INF & $\begin{array}{c}0.036 \\
(0.030)\end{array}$ & $\begin{array}{c}0.010 \\
(0.039)\end{array}$ & $\begin{array}{c}0.003 \\
(0.023)\end{array}$ & $\begin{array}{c}0.059 \\
(0.046)\end{array}$ & $\begin{array}{c}0.003 \\
(0.026)\end{array}$ \\
\hline $\ln K$ & $\begin{array}{l}0.181^{* * *} \\
(0.039)\end{array}$ & $\begin{array}{c}0.157^{* * *} \\
(0.042)\end{array}$ & $\begin{array}{l}0.112 * * * \\
(0.022)\end{array}$ & $\begin{array}{c}0.139 * * * \\
(0.047)\end{array}$ & $\begin{array}{c}0.158^{* * *} \\
(0.030)\end{array}$ \\
\hline EBIC & -91.141 & -109.957 & -126.293 & -114.201 & -123.421 \\
\hline $\operatorname{Adj}-R^{2}$ & 0.9874 & 0.9352 & 0.9665 & 0.9514 & 0.9689 \\
\hline McKinnon ADF test & 0.0211 & 0.0000 & 0.0001 & 0.0031 & 0.0000 \\
\hline
\end{tabular}

Note: The values in parentheses () show the standard error. ${ }^{* * *}, * *, *$ indicates the significance level of $1 \%, 5 \%$ and $10 \%$, respectively. 
Table 4. Ridge kink regression results for all five countries.

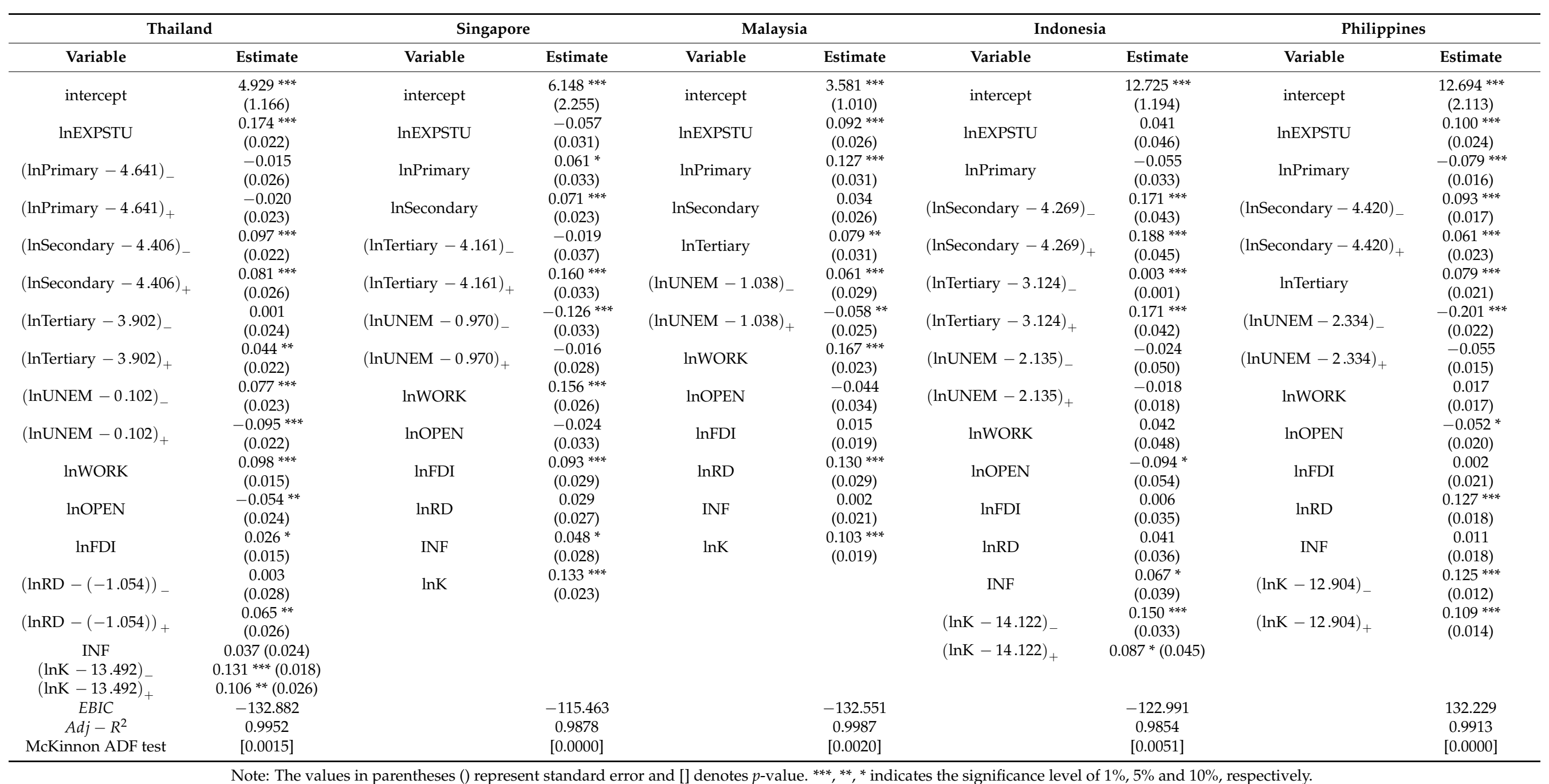

Note: The values in parentheses () represent standard error and [] denotes $p$-value. ${ }^{* * *},{ }^{* *},{ }^{*}$ indicates the significance level of $1 \%, 5 \%$ and $10 \%$, respectively. 
The empirical results for the ASEAN-5 countries obtained from the ridge kink regression model are provided in Table 4. As some of our variables are stationary at the first difference I(1), the spurious regression result is likely. Thus, we conduct the cointegration test of Engle and Granger [48] to confirm the long-run term relationship between the dependent variable and independent variables of our empirical models above. According to Engle and Granger [48], the absence of cointegration can be confirmed by the stationarity of the residuals of the model. Therefore, we use the McKinnon ADF test to investigate the cointegration in our kink model. This analysis is implemented in two steps. First, we estimate our kink regression model, and then the ADF test is applied to the error term series, obtained from the kink regression model, for unit root test. If the error is nonstationary or has a unit root, the null hypothesis of the existence of the cointegrating relationship can be rejected. The results of the cointegration test (McKinnon ADF test) for all empirical models are reported in the last row of Table 4 . We observe that the p-values of the McKinnon ADF test are less than 0.10 for all models. Thus, we can confirm the existence of long-runterm relationships in our empirical models.

According to Table 4, the results demonstrate different coefficient values that could indicate differences in the way education affects growth in different countries. Furthermore, all regime-dependent variables exhibit a different sign or value of the education effect on growth when the variation in values is above/below their corresponding kink parameters. We note that $\operatorname{lnEXPSTU}$, lnPrimary, $\ln$ Secondary, lnTertiary, lnUNEM, lnWORK refer to the education variables, while $\operatorname{lnOPEN}$, lnFDI, INF, and $\operatorname{lnK}$ are control variables. Overall, we observe that most of the education variables significantly affect the ASEAN-5 countries. $\operatorname{lnEXPSTU}$ shows a significant and positive coefficient of $0.174,0.092$, and 0.100 on the economic growth of Thailand, Malaysia, and the Philippines, respectively. The positive impact of higher education expenditure on growth can conform to the literature. Higher education is more likely to bring about the invention of new technology and the spillover effects from new knowledge relative to the secondary and primary education levels, but the higher stages of learning require more resources. However, our finding shows that more investment for higher education can finally bring about economic growth in Thailand, Malaysia, and the Philippines.

We also observe a significant linear effect of lnPrimary on economic growth in Singapore, Malaysia, and the Philippines. The primary school enrollment variable shows only a negative impact on the economic growth of the Philippines, an insignificant effect for Indonesia and Thailand (both two regimes), but a positive effect for Singapore and Malaysia. The positive impact of primary education enrollment on growth was found in many previous studies. Primary enrollment rates can attract investment in the physical capital, thereby promoting economic growth. On the other hand, the findings of a negative impact of primary education on the economic growth of the Philippines and an insignificant effect in Thailand and Indonesia are not new. These results are consistent with the findings of Abbas and Nasir [50]. Primary education is the first and basic level of education before continuing to the higher stages. Thus, primary education may not produce a direct and short-term effect on the economy. Still, it is important for long-term economic growth and lowered fertility rates. Moreover, Pritchett [51] suggested that primary educational quality might be too low to improve the cognitive skills or productivity of the labor, thereby creating no human capital. The estimates of the impact of secondary enrollment rates are found to be significant and positive in most of the countries, except Malaysia. Besides, the impact appears to be nonlinear for the case of Thailand, Indonesia, and the Philippines. In Singapore, a 1\% increase in the enrollment rate of secondary education would result in an approximately $0.071 \%$ increase in the economic growth. For the cases of Thailand, Indonesia, and the Philippines, similar results are obtained in that secondary education shows a significant and positive nonlinear impact on their economic growth. The estimated kink results indicate if $\operatorname{lnSecondary}$ is less than the kink point of $4.406(\exp (4.406)=81.941 \%)$ for Thailand, $4.161(\exp (4.269)=71.450 \%)$ for Indonesia, and $4.420(\exp (4.420)=83.096 \%)$ for the Philippines, then a $1 \%$ increase in $\operatorname{lnSecondary}$ can contribute to a $0.097 \%, 0.171 \%$, 
and $0.093 \%$ increase in economic growth of Thailand, Indonesia, and the Philippines, respectively. However, if lnSecondary is larger than their kink points, a 1\% increase in InSecondary can contribute to $0.081 \%, 0.188 \%$, and $0.061 \%$ increase in economic growth of Thailand, Indonesia, and the Philippines, respectively. It is noticed that the magnitude of the lnSecondary's effect on the economic growth of Thailand and Indonesia will become smaller, reflecting the operation of the law of diminishing returns of secondary education to economic growth. However, it can also be observed that the coefficient of lnSecondary effect for Indonesia is a bit higher in regime 2 (lnSecondary $>4.420$ ) than in regime 1 (lnSecondary $<4.420$ ). This indicates that the enrolment rate in secondary education has made a substantial contribution to the economic growth of Indonesia after the enrolment rate in secondary education increased beyond the kink point (4.406 or $83.096 \%)$.

While basic education can enhance economic growth, higher education measured by the tertiary enrollment rates can also play a vital role in economic growth in the ASEAN-5 countries. The results indicate that the estimated coefficients of lnTertiary are positive and significant for all ASEAN-5 countries. The impact of this variable on Thailand, Singapore, and Indonesia are distinguished into two regimes: regime 1 (lnTertiary $\leq \gamma_{\ln \text { Tertiary }}$ ) and regime 2 (lnTertiary $>\gamma_{\ln \text { Tertiary }}$ ). It is observed that, in the case of Thailand and Singapore, tertiary education has a significantly positive impact in regime 2 but this impact is insignificant in regime 1 . The results imply that if the enrollment rates in tertiary education are high enough—particularly greater than the kink point-it will significantly increase economic growth in these two countries. We have estimated the kink points for the enrollment rates and found that the significant kink points of Thailand and Singapore are $3.902(\exp (3.902)=49.501 \%$ for estimated enrollment rates) and 4.161 $(\exp (4.161)=64.135 \%)$, respectively. In addition, the tertiary enrollment rates positively impact growth in both regimes 1 and 2 for Indonesia, and the impact is more substantial when the enrollment rates are above the kink point. Even though Malaysia and Indonesia fail to find a nonlinear effect, the sign of the impact is steadily positive.

Apparently, there exists a kink effect of unemployment with advanced education in every country. However, not all the countries can observe significant impacts in both regimes 1 and 2. Thailand and Malaysia have similar results, that is, an increase in the share of the unemployed workers with advanced education will increase economic growth if the percentage share is not over the kink points $(\exp (0.102)=1.107 \%$ for Thailand and $\exp (1.038)=2.823 \%$ for Malaysia). However, if the share is greater than those kink points, it may harm economic growth. Besides, the results of Singapore and the Philippines are similar. We find that a lower share of unemployment with a higher degree can increase economic growth, but only for any level of the share of unemployment less than the kink point. However, the estimated impacts are insignificant in regime 2. It is not surprising when our findings indicate a negative relationship between high-skilled unemployment and economic growth as a high-skilled workforce is considered key to long-term economic growth. Therefore, an increase in the share of unemployment with a high degree will reduce the opportunity to transfer knowledge from universities to the other economic units, thereby impeding economic growth. On the other hand, we find a surprising result in a positive relationship between high-skilled unemployment and economic growth in Thailand and Malaysia (in regime 1). The possible explanation for the positive impact of unemployment on growth may refer to the Schumpeterian models of growth through creative destruction [52]. Quality-improving innovations drive economic growth by new entrants that make existing firms and jobs antiquated [53]. This is to say, the outmoded or old-fashioned firms will soon be replaced by the new tech companies and the workers employed in the no longer profitable firms are likely to lose their jobs entirely. So, the workers who do not have sufficient skills to work with the new technology are likely to lose their jobs, but that may lead to the overall economic growth due to technological development. This result is consistent with the finding of Fanati and Manfredi [54] and Vo and Ho [55]. Considering the lnWORK variable, only Thailand, Singapore, and Malaysia show a positive relationship between workforce education and economic growth. Among 
all countries, Malaysia's highly educated workforce has the most apparent effect on its economy, whereas Singapore takes second place, followed by Thailand.

With respect to the control variables, there is evidence of the linear effects of lnOPEN, $\operatorname{lnFDI}, \operatorname{lnRD}$, INF, and $\operatorname{lnK}$ on the economic growth of five countries (except for $\operatorname{lnRD}$ of Thailand, and lnK of Thailand, Indonesia, and the Philippines). We observe that lnOPEN of Thailand, Indonesia, and the Philippines have a negative and significant coefficient suggesting that the more liberalized the economies are, the less the impact on economic growth will be. The negative impact of trade openness on economic growth supports the previous findings of Belloumi and Alshehry [56]. The contribution of lnFDI to economic growth in Thailand and Singapore, in terms of the coefficients, are 0.026 and 0.093 , respectively. The contribution of foreign direct investment to economic growth in Singapore is relatively higher than in Thailand. For the variable INF, we find that its elasticity is positive and significant for Singapore, Indonesia, and the Philippines.

Regarding the nonlinear effect variables namely $\ln R D$ of Thailand, and $\operatorname{lnK}$ of Thailand, Indonesia, and the Philippines; $\operatorname{lnRD}$ is positive and statistically significant only in regime $2\left(\operatorname{lnRD}>\gamma_{\ln R D}\right)$ or when $\operatorname{lnRD}$ is higher than $-1.054(\exp (-0.1054)=0.348 \%$ of GDP $)$, while lnK shows a significant positive impact on economic growth in both the two regimes. However, as $\ln \mathrm{K}$ continues to expand and exceeds the kink point, its role in the economies of Thailand, Indonesia, and the Philippines slows down. This implies that the scale of the capital has not only a kink effect but also a diminishing marginal efficiency effect on economic growth.

In essence, the impact of education on the economic growth of ASEAN-5 countries is obviously nonlinear as some indicators, in particular, lnTertiary, lnSecondary, and lnUNEM, show a significant kink effect, and the magnitudes of the impact are different between the two regimes. Evidently, the expenditure on education, the enrolment rates of secondary education, and tertiary education are important factors that result in boosting the economic growth of ASEAN-5 countries. However, the percentage of the unemployed labor with advanced education is a vital factor harming the economic growth in all countries except for Thailand and Malaysia. The result shows a positive effect of the unemployment rate on the economic growth of Thailand and Malaysia when its value is less than $1.107 \%$ and $2.823 \%$, respectively. This indicates that when the unemployment rate is low, the increase in the unemployment rate, because of squeezing out of inefficient workers, could lead to the higher economic growth of Thailand and Malaysia. Furthermore, there is evidence that the major contributors to economic growth are the expenditure on education in Thailand, the enrollment rate of tertiary education (regime 2) in Singapore, the enrollment rate of primary education in Malaysia, the enrollment rate of secondary education (regime 2) in Indonesia, and the enrollment rate of secondary education (regime 1) in the Philippines.

\subsection{Result at the ASEAN-5 Region Level}

To investigate the overall impacts of education factors on the ASEAN-5's economic growth, this study further constructs the panel data analysis. In this section, the kink regression with ridge estimator is used in our analysis. Because the panel data are used, the kink regression model in Equation (1) can be rewritten into the form below:

$Y_{i t}=\beta_{1}^{-}\left(x_{1, i t}-\gamma_{1}\right)_{-}+\beta_{1}^{+}\left(x_{1, i t}-\gamma_{1}\right)_{+}+\ldots+\beta_{K}^{-}\left(x_{K, i t}-\gamma_{K}\right)_{-}+\beta_{K}^{+}\left(x_{K, i t}-\gamma_{K}\right)_{+}+\alpha Z_{i t}+u_{i}+e_{i t}$,

where $Y_{i t}$ is the dependent variable of country $i$ at time $t$. $X_{i t}$ denotes nonlinear independent variables, $Z_{i t}$ is a linear independent variable, $u_{i}$ indicates the individual effect of each country, and $e_{i t}$ is the random standard error of country $i$ at time $t$. To estimate the model, the fixed effect (FE) with ridge estimation is employed in this study. This estimation is preferable to the simple ridge alternative, as it includes the individual specific effect in the model to control for any unobserved country-specific effects in different countries and 
also to address the heterogeneity among countries. To deal with the unobserved $u_{i}$, all variables are transformed as follows:

$$
\begin{aligned}
& \widetilde{Y}_{i t}=Y_{i t}-\frac{1}{N} \sum_{i=1}^{N} Y_{i t}, \\
& \widetilde{X}_{i t}=X_{i t}-\frac{1}{N} \sum_{i=1}^{N} X_{i t}, \\
& \widetilde{Z}_{i t}=Z_{i t}-\frac{1}{N} \sum_{i=1}^{N} Z_{i t}, \\
& \widetilde{e}_{i t}=e_{i t}-\frac{1}{N} \sum_{i=1}^{N} e_{i t} .
\end{aligned}
$$

Then, we can rewrite our panel model (Equation (11)) as

$\widetilde{Y}_{i t}=\beta_{0}+\beta_{1}^{-}\left(\widetilde{X}_{1, i t}-\gamma\right)_{-}+\beta_{1}^{+}\left(\widetilde{X}_{1, i t}-\gamma\right)_{+}+\ldots+\beta_{K}^{-}\left(\widetilde{X}_{K, i t}-\gamma_{K}\right)_{-}+\beta_{1}^{+}\left(\widetilde{X}_{K, i t}-\gamma_{K}\right)_{+}+\alpha \widetilde{Z}_{i t}+\widetilde{e}_{i t}$

Then, we can use the ridge estimation (Section 3.2) for estimating $\beta=\left(\beta_{0}, \beta_{1}^{-}, \ldots, \beta_{K}^{-}\right.$, $\left.\beta_{1}^{+}, \ldots, \beta_{K}^{+}, \alpha\right)$ and $\gamma=\left(\gamma_{1}, \ldots, \gamma_{K}\right)$ of this fixed-effect model specification. Again, prior to conducting the panel analysis for the ASEAN-5 region, we need to test whether the kink effect exists for each variable. We use the F-statistic and bootstrap $p$-value as explained in Section 3.3. Table 5 presents the empirical results of the panel kink test for the ASEAN-5 region, which show that $\operatorname{lnEXPSTU}$, lnSecondary, lnTertiary, lnUNEM, lnOPEN, lnFDI, lnRD have nonlinear effects on the ASEAN-5's economic growth. After the panel kink test, we analyze the impacts of education on the economic growth of the ASEAN-5 from 2000 to 2018. Finally, we obtain the results of the panel kink regression as reported in Table 6.

Table 5. Panel kink effect test: $F_{k}^{*}$.

\begin{tabular}{ccccccc}
\hline & $\operatorname{lnEXPSTU}$ & $\ln$ Primary & $\operatorname{lnSecondary}$ & $\ln$ Tertiary & UNEM & $\operatorname{lnWORK}$ \\
\hline \multirow{2}{*}{ ASEAN-5 } & $\mathbf{6 . 3 8 0}$ & 4.612 & $\mathbf{8 . 2 6 3}$ & $\mathbf{6 . 1 3 1}$ & $\mathbf{1 4 . 1 8 1}$ & 3.421 \\
& $\mathbf{( 0 . 0 9 1 )}$ & $(0.231)$ & $\mathbf{( 0 . 0 0 0 )}$ & $\mathbf{( 0 . 0 5 5 )}$ & $\mathbf{( 0 . 0 0 0 )}$ & $(0.544)$ \\
\hline & $\operatorname{lnOPEN}$ & $\operatorname{lnFDI}$ & $\ln R \mathrm{D}$ & INF & $\operatorname{lnK}$ & \\
\hline \multirow{2}{*}{ ASEAN-5 } & $\mathbf{1 2 . 9 8 0}$ & $\mathbf{1 2 . 9 8 8}$ & $\mathbf{7 . 3 4 0}$ & 5.327 & 4.597 & \\
& $\mathbf{( 0 . 0 0 0 )}$ & $\mathbf{( 0 . 0 0 0 )}$ & $\mathbf{( 0 . 0 0 0 )}$ & $(0.451)$ & $(0.511)$ & \\
\hline
\end{tabular}

Note: The values in parentheses () are $p$-values. Bold number indicates significant kink effect.

Table 6 shows that between the education variables and economic growth, there is a nonlinear relationship. The nonlinear impacts of lnSecondary, lnTertiary, and lnUNEM are found in the individual country (see Section 5.1) and also appear in the panel analysis. The only difference is that the variables, namely lnEXPSTU, lnOPEN, and lnFDI, also have nonlinear impacts on the ASEAN-5 region's economic growth, which we will discuss in the following paragraph. Note that in this study, heterogeneity is controlled by a fixed effect. However, the fixed effect reflects only the heterogeneity in intercepts [57]; therefore, taking into account fixed effects is still restrictive in estimating the panel data model [58]. Specifically, the fixed effect estimation handles heterogeneity in the intercept, but not heterogeneity in the slope parameters. Therefore, the results from time-series and panel data could be inconsistent. This indicates that the nonlinear effects of these three variables are due to the heterogeneous characteristics of the countries.

Moreover, it is noteworthy to compare our ridge-fixed effect estimation with other methods to prove the robustness of our estimation adopted for application in the panel education-growth model. 
Table 6. Empirical results of the ASEAN-5 region obtained from the panel kink and the panel linear regressions.

\begin{tabular}{|c|c|c|c|c|c|c|c|}
\hline \multirow[b]{2}{*}{ Variable } & \multicolumn{3}{|c|}{ Panel Kink Regression } & & \multicolumn{3}{|c|}{ Panel Linear Regression } \\
\hline & $\begin{array}{l}\text { Ridge-Fixed } \\
\text { Effect }\end{array}$ & $\begin{array}{l}\text { Fixed } \\
\text { Effect }\end{array}$ & $\begin{array}{l}\text { Pooled } \\
\text { OLS }\end{array}$ & & $\begin{array}{l}\text { Ridge-Fixed } \\
\text { Effect }\end{array}$ & $\begin{array}{l}\text { Fixed } \\
\text { Effect }\end{array}$ & $\begin{array}{l}\text { Pooled } \\
\text { OLS }\end{array}$ \\
\hline intercept & $\begin{array}{l}8.947^{* *} \\
(0.981)\end{array}$ & $\begin{array}{l}6.311^{* *} \\
(1.235)\end{array}$ & $\begin{array}{l}7.554^{* *} \\
(1.556)\end{array}$ & intercept & $\begin{array}{l}7.183^{* * *} \\
(1.244)\end{array}$ & $\begin{array}{l}5.5241^{* * *} \\
(2.1254)\end{array}$ & $\begin{array}{l}6.351^{* * *} \\
(2.3121)\end{array}$ \\
\hline$(\operatorname{lnEXPSTU}-6.872)_{-}$ & $\begin{array}{l}0.066^{* * *} \\
(0.027)\end{array}$ & $\begin{array}{c}0.031 \\
(0.031)\end{array}$ & $\begin{array}{c}0.022 \\
(0.004)\end{array}$ & $\operatorname{lnEXPSTU}$ & $\begin{array}{l}0.038 * \\
(0.015)\end{array}$ & $\begin{array}{l}0.042 * \\
(0.016)\end{array}$ & $\begin{array}{l}0.040^{*} \\
(0.017)\end{array}$ \\
\hline$(\operatorname{lnEXPSTU}-6.872)_{+}$ & $\begin{array}{l}0.186^{* * *} \\
(0.031)\end{array}$ & $\begin{array}{l}0.201 * * * \\
(0.038)\end{array}$ & $\begin{array}{l}0.239 * * * \\
(0.054)\end{array}$ & lnPrimary & $\begin{array}{l}0.443^{* * *} \\
(0.156)\end{array}$ & $\begin{array}{l}0.459^{* * *} \\
(0.211)\end{array}$ & $\begin{array}{l}0.598^{* *} \\
(0.306)\end{array}$ \\
\hline lnPrimary & $\begin{array}{c}0.059 \\
(0.140)\end{array}$ & $\begin{array}{c}0.024 \\
(0.145)\end{array}$ & $\begin{array}{c}0.022 \\
(0.137)\end{array}$ & lnSecondary & $\begin{array}{c}0.058 \\
(0.216)\end{array}$ & $\begin{array}{c}0.097 \\
(0.331)\end{array}$ & $\begin{array}{c}0.066 \\
(0.354)\end{array}$ \\
\hline$(\operatorname{lnSecondary}-4.425)_{-}$ & $\begin{array}{c}0.128 \\
(0.174)\end{array}$ & $\begin{array}{c}0.094 \\
(0.201)\end{array}$ & $\begin{array}{c}0.084 \\
(0.214)\end{array}$ & lnTertiary & $\begin{array}{l}0.685^{* * *} \\
(0.031)\end{array}$ & $\begin{array}{l}0.703^{* * *} \\
(0.058)\end{array}$ & $\begin{array}{l}0.689^{* * *} \\
(0.042)\end{array}$ \\
\hline$(\operatorname{lnSecondary}-4.425)_{+}$ & $\begin{array}{l}0.894^{* * *} \\
(0.130)\end{array}$ & $\begin{array}{l}0.944^{* * *} \\
(0.208)\end{array}$ & $\begin{array}{l}0.997^{* * *} \\
(0.258)\end{array}$ & $\operatorname{lnUNEM}$ & $\begin{array}{l}0.579 * * * \\
(0.218)\end{array}$ & $\begin{array}{l}0.504 * * \\
(0.225)\end{array}$ & $\begin{array}{l}0.588^{* *} \\
(0.301)\end{array}$ \\
\hline$(\operatorname{lnTertiary}-3.633)_{-}$ & $\begin{array}{l}0.051^{* * *} \\
(0.011)\end{array}$ & $\begin{array}{l}0.031^{* * *} \\
(0.014)\end{array}$ & $\begin{array}{l}0.028 * \\
(0.017)\end{array}$ & $\operatorname{lnWORK}$ & $\begin{array}{l}0.256^{* * *} \\
(0.026)\end{array}$ & $\begin{array}{l}0.121^{* * *} \\
(0.043)\end{array}$ & $\begin{array}{l}0.116^{* *} \\
(0.053)\end{array}$ \\
\hline$(\operatorname{lnTertiary}-3.633)_{+}$ & $\begin{array}{l}0.749^{* * *} \\
(0.020)\end{array}$ & $\begin{array}{l}0.541^{* * *} \\
(0.103)\end{array}$ & $\begin{array}{l}0.587^{* * * *} \\
(0.233)\end{array}$ & $\operatorname{lnOPEN}$ & $\begin{array}{c}0.459 \\
(0.341)\end{array}$ & $\begin{array}{c}0.368 \\
(0.368)\end{array}$ & $\begin{array}{c}0.549 \\
(0.401)\end{array}$ \\
\hline$(\operatorname{lnUNEM}-1.316)_{-}$ & $\begin{array}{c}0.874 \\
(0.753)\end{array}$ & $\begin{array}{c}0.778 \\
(0.711)\end{array}$ & $\begin{array}{c}0.651 \\
(0.783)\end{array}$ & $\operatorname{lnFDI}$ & $\begin{array}{c}0.148 \\
(0.161)\end{array}$ & $\begin{array}{c}0.012 \\
(0.222)\end{array}$ & $\begin{array}{c}0.034 \\
(0.235)\end{array}$ \\
\hline$(\ln U N E M-1.316)_{+}$ & $\begin{array}{l}-1.265^{* * *} \\
(0.194)\end{array}$ & $\begin{array}{c}-1.002^{* * *} \\
(0.201)\end{array}$ & $\begin{array}{l}-1.115^{* *} \\
(0.241)\end{array}$ & $\ln R D$ & $\begin{array}{l}1.443^{* * *} \\
(0.254)\end{array}$ & $\begin{array}{l}1.511^{* * *} \\
(0.268)\end{array}$ & $\begin{array}{l}1.124^{* * *} \\
(0.254)\end{array}$ \\
\hline $\operatorname{lnWORK}$ & $\begin{array}{l}0.301^{* * *} \\
(0.021)\end{array}$ & $\begin{array}{c}0.416^{* * * *} \\
(0.103)\end{array}$ & $\begin{array}{l}0.497^{* * * *} \\
(0.201)\end{array}$ & INF & $\begin{array}{l}-0.001 \\
(0.002)\end{array}$ & $\begin{array}{l}-0.001 \\
(0.003)\end{array}$ & $\begin{array}{l}-0.001 \\
(0.002)\end{array}$ \\
\hline$(\operatorname{lnOPEN}-0.020)_{-}$ & $\begin{array}{l}-0.402 * \\
(0.231)\end{array}$ & $\begin{array}{l}-0.398^{*} \\
(0.264)\end{array}$ & $\begin{array}{l}-0.518 * \\
(0.298)\end{array}$ & $\ln K$ & $\begin{array}{c}0.031 \\
(0.035)\end{array}$ & $\begin{array}{c}0.026 \\
(0.042)\end{array}$ & $\begin{array}{c}0.013 \\
(0.051)\end{array}$ \\
\hline$(\operatorname{lnOPEN}-0.020)_{+}$ & $\begin{array}{l}0.738^{* *} \\
(0.326)\end{array}$ & $\begin{array}{l}0.722 * * \\
(0.268)\end{array}$ & $\begin{array}{c}0.601 \\
(0.401)\end{array}$ & & & & \\
\hline$(\operatorname{lnFDI}-1.083)_{-}$ & $\begin{array}{c}0.048 \\
(0.084)\end{array}$ & $\begin{array}{c}0.059 \\
(0.089)\end{array}$ & $\begin{array}{c}0.068 \\
(0.101)\end{array}$ & & & & \\
\hline$(\operatorname{lnFDI}-1.083)_{+}$ & $\begin{array}{l}0.756 * * \\
(0.251)\end{array}$ & $\begin{array}{l}0.561 * * \\
(0.259)\end{array}$ & $\begin{array}{c}0.439 \\
(0.278)\end{array}$ & & & & \\
\hline$(\operatorname{lnRD}-(-0.947))_{-}$ & $\begin{array}{l}0.405^{*} \\
(0.199)\end{array}$ & $\begin{array}{l}0.428 * \\
(0.214)\end{array}$ & $\begin{array}{c}0.305 \\
(0.206)\end{array}$ & & & & \\
\hline$(\operatorname{lnRD}-(-0.947))_{+}$ & $\begin{array}{l}0.958^{* * *} \\
(0.215)\end{array}$ & $\begin{array}{l}1.205^{* * *} \\
(0.365)\end{array}$ & $\begin{array}{l}1.358^{* * *} \\
(0.554)\end{array}$ & & & & \\
\hline INF & $\begin{array}{l}-0.089 \\
(0.100)\end{array}$ & $\begin{array}{l}-0.115 \\
(0.121)\end{array}$ & $\begin{array}{l}-0.126 \\
(0.189)\end{array}$ & & & & \\
\hline $\ln K$ & $\begin{array}{l}0.395^{*} \\
(0.235)\end{array}$ & $\begin{array}{l}0.348^{*} \\
(0.254)\end{array}$ & $\begin{array}{c}0.331 \\
(0.267)\end{array}$ & & & & \\
\hline EBIC & -439.350 & -412.896 & -359.35 & & -408.880 & -398.684 & -304.68 \\
\hline Adj $-R^{2}$ & 0.9944 & 0.9901 & 0.9899 & & 0.9874 & 0.9887 & 0.9543 \\
\hline
\end{tabular}

Note: The values in parentheses () represent standard error. ${ }^{* * *},{ }^{* *},{ }^{*}$ indicates the significance level of $1 \%, 5 \%$ and $10 \%$, respectively.

Therefore, we also consider the other two methods of estimation, namely fixed-effects and pooled OLS estimations, to test the robustness of the panel kink regression model. The results of kink and linear model estimations from the fixed-effects and pooled OLS variants are also reported in Table 6 . The coefficients of the estimated variables from the fixed-effects model in the ridge regression framework are consistent with those from the fixed-effect and the pooled OLS alternatives. This result indicates that the ridge-fixed effect model has a good robustness. Moreover, we compare the performance of the ridge-fixed effect panel kink regression with other models using the EBIC. The results reported in the second-last row of Table 6 indicate a higher performance of our panel kink regression with a ridge-fixed effect. Therefore, we will interpret the results from the ridge-fixed effect panel-kink regression model (located in the second column of Table 6). 
Now we turn to presenting the estimation of the panel kink regression with ridge-fixed effect. We find that the coefficients of lnPrimary and lnWORK are linear and positive. A highly educated workforce can positively affect the ASEAN-5's economic growth, while the enrollment rates of primary education do not signal direct benefits to the growth. This finding is in line with Keller [8], who revealed that primary enrollment rates do not directly affect economic growth globally, among developing and developed country subsamples (1960-2000). Nevertheless, primary enrollment rates can raise the secondary enrollment rates, which can significantly improve economic growth in this study.

Consider other education variables, lnEXPSTU, lnSecondary, lnTertiary, and lnUNEM. These variables are found to have nonlinear impacts on the economic growth. Firstly, public education expenditure per student at the tertiary level (lnEXPSTU) shows a positive slope for low $\operatorname{lnEXPSTU}$ with a significant kink point around $(\exp (6.872)=964.876$ USD per tertiary student), switching to a steeply positive slope for the lnEXPSTU beyond that kink value. The results imply that the higher expenditure on tertiary education, the more economic growth in the ASEAN-5 region. However, the positive impacts appear to be stronger when the expenditure is beyond the kink point (964.876 USD per tertiary student). Expenditure per tertiary student also includes grants/loans for higher-education students. Increased expenditure per tertiary student may increase the opportunity for poorer students to access the tertiary education. As a result, highly educated workers are supplied more to the labor market.

Secondly, the results show that the impacts of lnSecondary and lnTertiary are statistically significant and positive. When $\ln$ Secondary and lnTertiary exceed their kink points of 4.425 and 3.633, the contributions of the secondary and tertiary enrollment rates to the ASEAN-5's economic growth are 0.894 and 0.749 , respectively. However, when lnTertiary is below its kink point, its contribution decreases to 0.051 while lnSecondary is statistically insignificant. There is no doubt that both levels of education can contribute substantially to economic growth. Interestingly, the magnitude of lnSecondary is slightly larger than lnTertiary $(0.894>0.749)$ in regime 2 . The result implies that secondary education can provide better economic returns or contribute more to the economy than higher education. The importance of secondary education, therefore, deserves our consideration. Secondary education enables workers to produce goods and services and use technology in their workplace. As the majority of the labor force in the ASEAN-5 region usually have secondary education, we might conclude that, so far, the ASEAN-5's economic growth has mainly been driven by secondary-school educated workers. However, the impacts of secondary and tertiary education levels are indistinguishable. According to the PISA surveys, the quality of secondary education can positively affect the efficiency of the tertiary education systems. Secondary-school students who have solid skills will be more likely to succeed when advancing to tertiary education than those with poorer skills. Hence, secondary education may indirectly enhance economic growth through its spillover effects on tertiary education. Thirdly, unemployment with advanced education (lnUNEM) has significant negative impacts on economic growth in ASEAN-5, as shown by a significant and negative coefficient of -1.265 . However, the estimated result of regime 1 is not significant. The negative coefficient of lnUNEM indicates that for any level of the share of unemployment with advanced education in the total unemployment larger than the kink point $(\exp (1.316)$ $=3.728 \%$ ), an increase in lnUNEM by $1 \%$ will lead to a decrease in the economic growth of the ASEAN-5 region by $1.265 \%$.

Lastly, we turn into the control variables. The nonlinear relationships exist between trade openness, FDI, and RD. All the nonlinear control variables are relevant factors boosting economic growth in the regional analysis, except for the trade openness in regime 1. We observe that when the trade openness is below its kink point $(\exp (0.020)=1.020$ times the GDP), the higher trade openness does not lead to a substantial increase in economic growth, but the impact is rather negative. The result also reports that inflation has an estimated insignificant effect, while capital is positive and significant in the ASEAN-5 region. Besides, our findings reveal that $\mathrm{RD}$ is productivity enhancing. The impacts 
of RD on the ASEAN-5's economic growth are larger when RD expenditure increases. In particular, the increases are twofold-in terms of the size of the coefficient-if RD expenditure is greater than the kink point $(\exp (0.947)=2.578 \%$ of GDP $)$.

Besides, to illustrate an overview of the nonlinear effects of some education indicators as well as some control variables on the ASEAN-5's economic growth, we depict the kink regression lines (red) in Figure 1. The horizontal axis is the nonlinear independent variable, while the vertical axis is economic growth (lnGDP). We can see that the coefficient slopes change when the education variables exceed their kink points. The regression line switches from the positive slope to the negative slope for the lnUNEM variable, from the negative slope to the positive slope for $\operatorname{lnOPEN}$ and $\operatorname{lnFDI}$, and from weak positive to more substantially positive for $\operatorname{lnEXPSTU}$, $\ln S$ econdary, $\ln$ Tertiary, and $\operatorname{lnRD}$. This illustration proves that there are nonlinear impacts of education on the economic growth in ASEAN-5.
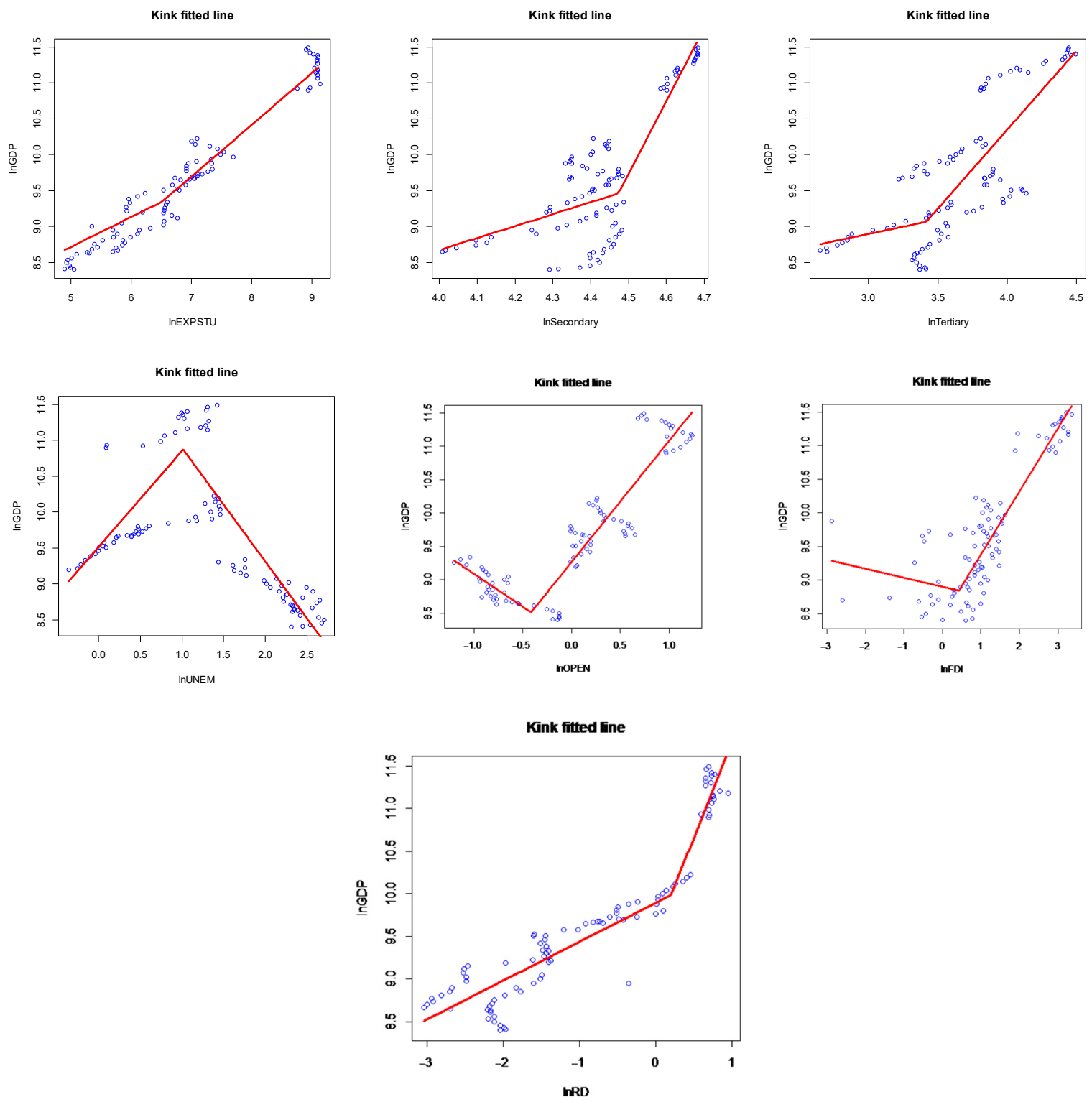

Figure 1. Panel kink regression lines between ASEAN-5 economic growth and its nonlinear covariates.

\section{Conclusions}

This study explored the nonlinear impacts of education (especially higher education) on economic growth in ASEAN-5 countries (i.e., Thailand, Indonesia, Malaysia, Singapore, 
and the Philippines) over the period 2000-2018. The influences of education are evaluated through public expenditure on tertiary education per student, enrolment rates of primary, secondary, and tertiary levels, educated workforce, and the novelty of unemployment rates with advanced education along with the control variables: trade openness, FDI, research and development, inflation rate, and capital stocks. To perform the empirical analysis, we use the time-series kink regression and the panel kink regression to examine the nonlinear impacts of education on economic growth. Firstly, the time-series kink regression is estimated using the ridge estimation to examine the kink effect on the relationship between economic growth and each education variable as well as the control variables for all five countries in ASEAN-5 separately. Secondly, the panel kink regression estimated by the ridge estimator is conducted to examine and confirm the overall nonlinear educationgrowth nexus in the ASEAN-5 region. Note that this study considers the ridge estimation as many education variables are considered, while the ASEAN-5 data are limited. The multicollinearity problem and the problems of a small dataset are, respectively, of concern. Therefore, the ridge estimation is employed to fit the kink regression model for both time-series and panel cases.

The overall results suggest that the impacts of education on the ASEAN-5's economic growth do not indicate a linear relationship, but rather appear in line with the kink effect. The analyses of the individual country (time series) and the ASEAN-5 region (panel) are almost consistent and coherent, and they confirm the nonlinear impacts of some education indicators - especially the enrollment rates of secondary and tertiary education-on economic growth. It is evident that the magnitude of the education impacts is different depending on whether the coefficient value of the education variable is below or above its kink point. Considering individual country (time series) analysis, enrollment rates of secondary and tertiary education and the unemployment with advanced education have nonlinear impacts on economic growth in most ASEAN-5 countries. The number of unemployed graduates shows a negative impact on the economic growth in all countries except for Thailand and Malaysia which can be positive, while enrollment rates in secondary and tertiary education can significantly generate higher economic growth in most of the countries. However, the enrollment rates in tertiary education greater than the kink points $(49.5 \%, 22.4 \%$, and $64.14 \%)$ can generate larger impacts on economic growth in Thailand, Indonesia, and Singapore, respectively. Lastly, the results from the panel analysis reveal that the impacts of public expenditure per tertiary student on the ASEAN-5's economic growth are nonlinear, so are the enrollment rates of secondary and tertiary education, and unemployment with advanced education. Our findings show that the higher expenditure on the tertiary student, the greater the economic growth in the ASEAN-5 region. Additionally, secondary school enrollment can have significant and positive impacts on the growth if the enrollment rates are above the kink point, 83.513\%. However, the impact of the enrollment rates of tertiary level can become twice as strong if the enrollment rates are greater than the kink point, 37.826\%.

\section{Policy Recommendations}

Based on the empirical results, the following recommendations can be made to foster economic growth further.

First, this study finds that the secondary and tertiary enrollment rates are significant for the ASEAN-5's economic growth (both individual country and region). However, our analysis shows that there exist significant kink points of these education variables. Secondary education in terms of enrollment rates can only contribute to economic growth if the enrollment rates are greater than the kink point. Besides, the impacts of tertiary education in terms of the enrollment rates can become larger if the rates are beyond its kink point. Therefore, the government should pay attention to the kink values and impose the education policy that can help increase or at least maintain the enrollment rates of these two education levels in the ASEAN-5 region. 
Second, the results of the individual country analysis and the regional analysis demonstrate the importance of the public expenditure per tertiary student. In particular, the regional analysis shows that the impacts of the expenditure on economic growth tend to increase when the expenditure is larger than the kink value (964.876 USD per tertiary student). This is the estimated result for the average ASEAN-5 region. However, according to the obtained data, most of the countries in ASEAN-5 have higher expenditure per tertiary student than the kink value, except for Indonesia and Malaysia which have lower expenditure than the estimated kink value. Some previous studies suggested that expenditure per student is beneficial for the economy in the early stage, but after that the impacts will be reduced due to the diminishing returns at higher expenditure levels. However, our findings reveal that this might not be true for the expenditure per student at the advanced education levels. There are higher returns on the investment at tertiary education. Unlike the skills obtained from basic education, technology and knowledge obtained from the universities never stop developing due to further research and development. Investment in tertiary education can bring about greater productivity, more innovation, and more creativity, which are the key to the knowledge-based economy.

Lastly, the unemployment rates with advanced education are considered a novelty in this study. We presume that the relationship between unemployment with advanced education and economic growth should be negative. The estimated results can conform to our hypothesis in many ASEAN-5 countries, except for Thailand and Malaysia. An increase in the share of the unemployment of advanced educated workers in the total unemployment appears to affect positively the economic growth of Thailand and Malaysia when the shares are below the kink values, $1.107 \%$ and $2.823 \%$, respectively. However, when the shares of unemployment with advanced education in the total unemployment of these two countries exceed the kink values, the negative impacts on the growth are found. Hence, the governments of these two countries need to provide an appropriate policy to maintain the share of the unemployment with advanced education of Thailand and Malaysia at levels lower than $1.107 \%$ and $2.823 \%$, respectively.

Author Contributions: Conceptualization, W.Y. and P.M.; methodology, W.Y.; software, W.Y.; validation, P.M.; formal analysis, W.Y. and P.M.; investigation, P.M. and W.Y.; resources, P.M.; data curation, P.M.; writing—original draft preparation, P.M. and W.Y.; writing—review and editing, P.M. and W.Y. Both authors have read and agreed to the published version of the manuscript.

Funding: This research was funded by Thailand Research Fund (TRF), MRG6280147, and the Center of Excellence in Econometrics, Chiang Mai University.

Institutional Review Board Statement: Not applicable.

Informed Consent Statement: Not applicable.

Data Availability Statement: Data presented in this study are available on request from the corresponding author.

Acknowledgments: The authors would like to express their gratitude to Laxmi Worachai for her help and constant support to us, and Payap Tarkhamtham, a senior researcher of the Center of Excellence in Econometrics, Chiang Mai University, for his help with data collection.

Conflicts of Interest: The authors declare no conflict of interest. 


\section{Appendix A}

Table A1. Descriptive statistics for five countries (Time series data).

\begin{tabular}{|c|c|c|c|c|c|c|c|c|c|c|c|c|}
\hline Statistic & $\operatorname{lnGDP}$ & lnEXPSTU & lnPrimary & lnSecondary & lnTertiary & lnUNEM & lnWORK & lnOPEN & FDI & RD & INF & $\ln K$ \\
\hline & \multicolumn{12}{|c|}{ Thailand } \\
\hline Mean & 9.523 & 6.627 & 4.642 & 4.406 & 3.921 & 0.102 & 10.521 & 0.081 & 0.934 & -1.054 & 2.089 & 13.493 \\
\hline Maximum & 9.803 & 7.355 & 4.663 & 4.484 & 4.135 & 0.475 & 10.582 & 0.196 & 1.480 & 0.098 & 5.469 & 13.984 \\
\hline Minimum & 9.192 & 5.925 & 4.619 & 4.283 & 3.709 & -0.357 & 10.404 & -0.013 & -0.474 & -1.605 & -0.900 & 12.816 \\
\hline Std. Dev. & 0.185 & 0.498 & 0.013 & 0.066 & 0.119 & 0.261 & 0.054 & 0.075 & 0.577 & 0.549 & 1.769 & 0.421 \\
\hline ADF-Level & 0.985 & 0.984 & 0.112 & 0.999 & 0.813 & 0.865 & 0.898 & 0.101 & 0.307 & 0.912 & 0.277 & 0.999 \\
\hline \multirow[t]{2}{*}{$\begin{array}{c}\text { ADF-1st } \\
\text { diff }\end{array}$} & 0.000 & 0.099 & 0.000 & 0.021 & 0.001 & 0.094 & 0.040 & 0.000 & 0.000 & 0.084 & 0.000 & 0.071 \\
\hline & \multicolumn{12}{|c|}{ Singapore } \\
\hline Mean & 11.212 & 9.033 & 4.594 & 4.643 & 4.161 & 0.970 & 6.216 & 0.997 & 2.899 & 0.726 & 1.623 & 13.142 \\
\hline Maximum & 11.490 & 9.139 & 4.624 & 4.683 & 4.494 & 1.423 & 6.735 & 1.239 & 3.364 & 0.954 & 6.628 & 13.747 \\
\hline Minimum & 10.896 & 8.762 & 4.558 & 4.585 & 3.807 & 0.086 & 5.500 & 0.682 & 1.895 & 0.597 & -0.532 & 12.459 \\
\hline Std. Dev. & 0.189 & 0.095 & 0.024 & 0.036 & 0.258 & 0.385 & 0.373 & 0.172 & 0.404 & 0.078 & 1.971 & 0.473 \\
\hline ADF-Level & 0.999 & 0.639 & 0.893 & 0.977 & 0.999 & 0.941 & 0.999 & 0.303 & 0.903 & 0.690 & 0.109 & 0.990 \\
\hline $\begin{array}{l}\text { ADF-1st } \\
\text { diff }\end{array}$ & 0.020 & 0.000 & 0.000 & 0.000 & 0.021 & 0.006 & 0.074 & 0.000 & 0.000 & 0.000 & 0.000 & 0.089 \\
\hline Mean & 9.923 & 7.155 & 4.613 & 4.388 & 3.536 & 1.038 & 7.860 & 0.411 & 0.943 & -0.135 & 2.240 & 12.978 \\
\hline Maximum & 10.223 & 7.703 & 4.663 & 4.448 & 3.845 & 1.459 & 8.391 & 0.653 & 1.624 & 0.457 & 5.441 & 13.584 \\
\hline Minimum & 9.659 & 6.731 & 4.571 & 4.332 & 3.219 & 0.337 & 7.232 & 0.175 & -2.870 & -0.757 & 0.583 & 12.212 \\
\hline Std. Dev. & 0.178 & 0.260 & 0.031 & 0.042 & 0.201 & 0.419 & 0.372 & 0.153 & 1.030 & 0.398 & 1.196 & 0.506 \\
\hline ADF-Level & 0.999 & 0.801 & 0.995 & 0.800 & 0.990 & 0.861 & 1.000 & 0.142 & 0.157 & 0.999 & 0.637 & 0.978 \\
\hline \multirow[t]{2}{*}{$\begin{array}{c}\text { ADF-1st } \\
\text { diff }\end{array}$} & 0.094 & 0.000 & 0.015 & 0.002 & 0.006 & 0.000 & 0.100 & 0.008 & 0.000 & 0.009 & 0.000 & 0.100 \\
\hline & \multicolumn{12}{|c|}{ Indonesia } \\
\hline Mean & 9.039 & 6.341 & 4.679 & 4.312 & 3.202 & 2.065 & 9.161 & -0.903 & 0.325 & -2.180 & 3.925 & 14.327 \\
\hline Maximum & 9.339 & 6.772 & 4.700 & 4.488 & 3.596 & 2.653 & 9.681 & -0.655 & 1.070 & -0.355 & 8.200 & 14.914 \\
\hline Minimum & 8.699 & 5.753 & 4.660 & 4.046 & 2.695 & 1.435 & 8.491 & -1.202 & -2.602 & -2.996 & 0.700 & 13.057 \\
\hline Std. Dev. & 0.199 & 0.328 & 0.014 & 0.145 & 0.315 & 0.392 & 0.365 & 0.152 & 0.928 & 0.730 & 1.905 & 0.615 \\
\hline
\end{tabular}


Table A1. Cont.

\begin{tabular}{|c|c|c|c|c|c|c|c|c|c|c|c|c|}
\hline Statistic & $\operatorname{lnGDP}$ & lnEXPSTU & lnPrimary & lnSecondary & lnTertiary & lnUNEM & lnWORK & lnOPEN & FDI & RD & INF & $\ln K$ \\
\hline & \multicolumn{12}{|c|}{ Philippines } \\
\hline ADF-Level & 0.999 & 0.987 & 0.498 & 0.999 & 0.999 & 0.186 & 0.925 & 0.951 & 0.126 & 0.123 & 0.170 & 0.981 \\
\hline $\begin{array}{c}\text { ADF-1st } \\
\text { diff }\end{array}$ & 0.075 & 0.003 & 0.000 & 0.003 & 0.016 & 0.000 & 0.015 & 0.000 & 0.000 & 0.000 & 0.000 & 0.098 \\
\hline Mean & 8.677 & 5.296 & 4.686 & 4.421 & 3.426 & 2.335 & 9.213 & -0.518 & 0.356 & -1.982 & 3.908 & 12.905 \\
\hline Maximum & 9.050 & 5.844 & 4.728 & 4.483 & 3.573 & 2.708 & 9.267 & -0.124 & 1.185 & -1.492 & 8.260 & 13.332 \\
\hline Minimum & 8.402 & 4.904 & 4.644 & 4.291 & 3.315 & 1.988 & 9.155 & -0.869 & -0.623 & -2.207 & 0.674 & 12.295 \\
\hline Std. Dev. & 0.205 & 0.310 & 0.024 & 0.052 & 0.087 & 0.208 & 0.037 & 0.301 & 0.554 & 0.232 & 1.824 & 0.403 \\
\hline ADF-Level & 0.845 & 0.918 & 0.680 & 0.987 & 0.925 & 0.230 & 0.613 & 0.815 & 0.528 & 0.976 & 0.272 & 0.980 \\
\hline $\begin{array}{c}\text { ADF-1st } \\
\text { diff }\end{array}$ & 0.054 & 0.000 & 0.023 & 0.012 & 0.000 & 0.006 & 0.000 & 0.007 & 0.000 & 0.002 & 0.000 & 0.008 \\
\hline
\end{tabular}

Note: $p$ values are reported in parentheses.

Table A2. Descriptive statistics for ASEAN-5 (panel data).

\begin{tabular}{|c|c|c|c|c|c|c|c|c|c|c|c|c|}
\hline Statistic & $\operatorname{lnGDP}$ & $\operatorname{lnEXPSTU}$ & lnPrimary & lnSecondary & lnTertiary & lnUNEM & lnWORK & lnOPEN & $\operatorname{lnFDI}$ & $\ln R D$ & INF & $\ln K$ \\
\hline Mean & 9.695 & 6.908 & 4.642 & 4.438 & 3.664 & 1.277 & 8.576 & 0.043 & 1.117 & -0.884 & 2.719 & 13.338 \\
\hline Median & 9.578 & 6.790 & 4.647 & 4.432 & 3.604 & 1.308 & 9.146 & 0.098 & 1.055 & -0.968 & 2.591 & 13.315 \\
\hline Maximum & 11.490 & 9.139 & 4.728 & 4.683 & 4.494 & 2.708 & 10.582 & 1.239 & 3.364 & 0.954 & 8.260 & 14.914 \\
\hline Std. Dev. & 0.908 & 1.293 & 0.042 & 0.134 & 0.400 & 0.880 & 1.511 & 0.689 & 1.191 & 1.184 & 1.964 & 0.690 \\
\hline Skewness & 0.609 & 0.441 & -0.177 & -0.089 & 0.040 & -0.070 & -0.411 & -0.040 & -0.256 & 0.039 & 0.534 & 0.520 \\
\hline Kurtosis & 2.276 & 2.212 & 2.190 & 3.508 & 2.783 & 1.815 & 2.074 & 1.918 & 4.150 & 1.645 & 2.997 & 2.834 \\
\hline LLC-Level & $(0.000)$ & $(0.000)$ & $(0.000)$ & $(0.000)$ & $(0.000)$ & $(0.000)$ & $(0.000)$ & $(0.000)$ & $(0.000)$ & $(0.000)$ & $(0.000)$ & $(0.000)$ \\
\hline
\end{tabular}


Table A3. Correlations for Thailand.

\begin{tabular}{|c|c|c|c|c|c|c|c|c|c|c|c|}
\hline Variable & lnEXPSTU & lnPrimary & lnSecondary & lnTertiary & $\ln U N E M$ & $\operatorname{lnWORK}$ & lnOPEN & $\ln F D I$ & $\ln R D$ & INF & $\ln K$ \\
\hline $\operatorname{lnEXPSTU}$ & 1.000 & & & & & & & & & & \\
\hline lnPrimary & -0.820 & 1.000 & & & & & & & & & \\
\hline lnSecondary & 0.911 & -0.861 & 1.000 & & & & & & & & \\
\hline lnTertiary & -0.048 & -0.023 & 0.166 & 1.000 & & & & & & & \\
\hline lnUNEM & 0.925 & -0.939 & 0.918 & -0.032 & 1.000 & & & & & & \\
\hline lnWORK & 0.845 & -0.714 & 0.943 & 0.219 & 0.781 & 1.000 & & & & & \\
\hline $\operatorname{lnOPEN}$ & -0.078 & 0.134 & 0.113 & 0.291 & -0.159 & 0.264 & 1.000 & & & & \\
\hline $\operatorname{lnFDI}$ & -0.601 & 0.458 & -0.462 & 0.211 & -0.600 & -0.373 & 0.227 & 1.000 & & & \\
\hline $\ln R D$ & 0.758 & -0.845 & 0.647 & -0.229 & 0.860 & 0.447 & -0.431 & -0.487 & 1.000 & & \\
\hline $\operatorname{lnINF}$ & -0.289 & 0.283 & -0.110 & 0.401 & -0.348 & -0.011 & 0.843 & 0.401 & -0.447 & 1.000 & \\
\hline $\ln K$ & 0.956 & -0.817 & 0.974 & 0.080 & 0.900 & 0.950 & 0.121 & -0.493 & 0.647 & -0.111 & 1.000 \\
\hline
\end{tabular}

Note: To simplify the results, we highlight the strength of the correlation in color for the absolute values of the correlation ranging between $0-$ and 0.30 (green), between 0.31 - and 0.80 (yellow), and between 0.81 - and 1.0 (orange) which indicate the weak, moderate, and strong correlation, respectively.

Table A4. Correlations for Singapore.

\begin{tabular}{|c|c|c|c|c|c|c|c|c|c|c|c|}
\hline Variable & $\operatorname{lnEXPSTU}$ & lnPrimary & lnSecondary & lnTertiary & lnUNEM & $\operatorname{lnWORK}$ & $\operatorname{lnOPEN}$ & $\operatorname{lnFDI}$ & $\ln R D$ & INF & $\ln K$ \\
\hline $\operatorname{lnEXPSTU}$ & 1.000 & & & & & & & & & & \\
\hline lnPrimary & 0.215 & 1.000 & & & & & & & & & \\
\hline lnSecondary & 0.187 & 0.966 & 1.000 & & & & & & & & \\
\hline lnTertiary & 0.106 & 0.933 & 0.981 & 1.000 & & & & & & & \\
\hline $\operatorname{lnUNEM}$ & 0.176 & 0.621 & 0.668 & 0.678 & 1.000 & & & & & & \\
\hline $\operatorname{lnWORK}$ & 0.131 & 0.876 & 0.949 & 0.967 & 0.796 & 1.000 & & & & & \\
\hline $\operatorname{lnOPEN}$ & 0.523 & -0.507 & -0.617 & -0.663 & -0.313 & -0.618 & 1.000 & & & & \\
\hline $\operatorname{lnFDI}$ & 0.119 & 0.409 & 0.501 & 0.462 & 0.373 & 0.466 & -0.352 & 1.000 & & & \\
\hline $\operatorname{lnRD}$ & 0.224 & -0.126 & -0.085 & -0.044 & 0.332 & 0.056 & 0.362 & -0.297 & 1.000 & & \\
\hline INF & 0.454 & 0.256 & 0.112 & 0.067 & 0.101 & 0.059 & 0.446 & -0.258 & 0.339 & 1.000 & \\
\hline $\ln K$ & 0.121 & 0.920 & 0.968 & 0.988 & 0.741 & 0.979 & -0.635 & 0.421 & 0.033 & 0.140 & 1.000 \\
\hline
\end{tabular}

Note: To simplify the results, we highlight the strength of the correlation in color for the absolute values of the correlation ranging between 0 - and 0.30 (green), between 0.31 - and 0.80 (yellow), and between 0.81 - and 1.0 (orange) which indicate the weak, moderate, and strong correlation, respectively.

Table A5. Correlations for Malaysia.

\begin{tabular}{|c|c|c|c|c|c|c|c|c|c|c|c|}
\hline Variable & $\operatorname{lnEXPSTU}$ & lnPrimary & lnSecondary & lnTertiary & $\operatorname{lnUNEM}$ & lnWORK & $\operatorname{lnOPEN}$ & $\operatorname{lnFDI}$ & $\ln R D$ & INF & $\ln K$ \\
\hline $\operatorname{lnEXPSTU}$ & 1.000 & & & & & & & & & & \\
\hline lnPrimary & 0.393 & 1.000 & & & & & & & & & \\
\hline lnSecondary & 0.073 & 0.719 & 1.000 & & & & & & & & \\
\hline lnTertiary & 0.535 & 0.859 & 0.591 & 1.000 & & & & & & & \\
\hline $\operatorname{lnUNEM}$ & 0.687 & 0.749 & 0.331 & 0.868 & 1.000 & & & & & & \\
\hline $\operatorname{lnWORK}$ & 0.568 & 0.889 & 0.568 & 0.975 & 0.911 & 1.000 & & & & & \\
\hline $\operatorname{lnOPEN}$ & -0.654 & -0.806 & -0.444 & -0.955 & -0.897 & -0.947 & 1.000 & & & & \\
\hline $\operatorname{lnFDI}$ & 0.017 & 0.075 & 0.117 & 0.082 & 0.162 & 0.102 & 0.027 & 1.000 & & & \\
\hline $\ln R D$ & 0.487 & 0.896 & 0.536 & 0.966 & 0.862 & 0.973 & -0.947 & 0.010 & 1.000 & & \\
\hline INF & 0.005 & 0.057 & 0.063 & 0.065 & 0.337 & 0.144 & -0.057 & 0.371 & 0.054 & 1.000 & \\
\hline $\ln K$ & 0.678 & 0.859 & 0.466 & 0.932 & 0.959 & 0.974 & -0.939 & 0.142 & 0.931 & 0.181 & 1.000 \\
\hline
\end{tabular}

Note: To simplify the results, we highlight the strength of the correlation in color for the absolute values of the correlation ranging between 0 - and 0.30 (green), between 0.31 - and 0.80 (yellow), and between 0.81 - and 1.0 (orange) which indicate the weak, moderate, and strong correlation, respectively. 
Table A6. Correlations for Indonesia.

\begin{tabular}{|c|c|c|c|c|c|c|c|c|c|c|c|}
\hline Variable & $\operatorname{lnEXPSTU}$ & lnPrimary & lnSecondary & lnTertiary & $\operatorname{lnUNEM}$ & $\operatorname{lnWORK}$ & \multicolumn{2}{|c|}{$\operatorname{lnOPEN} \ln F D I$} & $\ln R D$ & INF & $\ln K$ \\
\hline $\operatorname{lnEXPSTU}$ & 1.000 & & & & & & & & & & \\
\hline lnPrimary & -0.505 & 1.000 & & & & & & & & & \\
\hline $\operatorname{lnSecondary}$ & 0.963 & -0.627 & 1.000 & & & & & & & & \\
\hline lnTertiary & 0.947 & -0.696 & 0.976 & 1.000 & & & & & & & \\
\hline $\operatorname{lnUNEM}$ & -0.822 & 0.719 & -0.824 & -0.900 & 1.000 & & & & & & \\
\hline $\operatorname{lnWORK}$ & 0.792 & -0.604 & 0.837 & 0.860 & -0.687 & 1.000 & & & & & \\
\hline $\operatorname{lnOPEN}$ & -0.724 & 0.599 & -0.807 & -0.808 & 0.704 & -0.787 & 1.000 & & & & \\
\hline $\operatorname{lnFDI}$ & 0.674 & -0.414 & 0.676 & 0.612 & -0.452 & 0.432 & -0.442 & 1.000 & & & \\
\hline $\ln R D$ & 0.211 & -0.372 & 0.304 & 0.304 & -0.136 & 0.196 & -0.077 & 0.213 & 1.000 & & \\
\hline INF & -0.433 & 0.208 & -0.458 & -0.445 & 0.449 & -0.493 & 0.746 & -0.170 & 0.305 & 1.000 & \\
\hline $\ln K$ & 0.977 & -0.608 & 0.985 & 0.959 & -0.816 & 0.777 & -0.757 & 0.729 & 0.312 & -0.380 & 1.000 \\
\hline
\end{tabular}

Note: To simplify the results, we highlight the strength of the correlation in color for the absolute values of the correlation ranging between 0 - and 0.30 (green), between 0.31 - and 0.80 (yellow), and between 0.81 - and 1.0 (orange) which indicate the weak, moderate, and strong correlation, respectively.

Table A7. Correlations for Philippines.

\begin{tabular}{|c|c|c|c|c|c|c|c|c|c|c|c|}
\hline Variable & $\operatorname{lnEXPSTU}$ & lnPrimary & lnSecondary & lnTertiary & $\operatorname{lnUNEM}$ & lnWORK & $\operatorname{lnOPEN}$ & $\operatorname{lnFDI}$ & $\ln R D$ & INF & $\ln K$ \\
\hline $\operatorname{lnEXPSTU}$ & 1.000 & & & & & & & & & & \\
\hline lnPrimary & 0.628 & 1.000 & & & & & & & & & \\
\hline lnSecondary & 0.758 & 0.343 & 1.000 & & & & & & & & \\
\hline lnTertiary & 0.809 & 0.692 & 0.561 & 1.000 & & & & & & & \\
\hline $\operatorname{lnUNEM}$ & -0.803 & -0.405 & -0.445 & -0.733 & 1.000 & & & & & & \\
\hline $\operatorname{lnWORK}$ & 0.037 & 0.024 & 0.032 & -0.053 & -0.249 & 1.000 & & & & & \\
\hline $\operatorname{lnOPEN}$ & -0.878 & -0.601 & -0.782 & -0.669 & 0.764 & -0.123 & 1.000 & & & & \\
\hline $\operatorname{lnFDI}$ & 0.400 & 0.018 & 0.239 & 0.548 & -0.599 & 0.180 & -0.192 & 1.000 & & & \\
\hline $\ln R D$ & 0.610 & 0.310 & 0.403 & 0.829 & -0.639 & -0.091 & -0.351 & 0.788 & 1.000 & & \\
\hline INF & -0.363 & -0.525 & -0.308 & -0.438 & 0.294 & 0.121 & 0.333 & -0.293 & -0.351 & 1.000 & \\
\hline $\ln K$ & 0.904 & 0.461 & 0.843 & 0.719 & -0.818 & 0.144 & -0.955 & 0.357 & 0.482 & -0.277 & 1.000 \\
\hline
\end{tabular}

Note: To simplify the results, we highlight the strength of the correlation in color for the absolute values of the correlation ranging between $0-$ and 0.30 (green), between 0.31 - and 0.80 (yellow), and between 0.81 - and 1.0 (orange) which indicate the weak, moderate, and strong correlation, respectively.

Table A8. Correlations for ASEAN-5.

\begin{tabular}{|c|c|c|c|c|c|c|c|c|c|c|c|}
\hline Variable & lnEXPSTU & lnPrimary & lnSecondary & lnTertiary & $\operatorname{lnUNEM}$ & lnWORK & lnOPEN & $\operatorname{lnFDI}$ & $\ln R D$ & INF & $\ln K$ \\
\hline $\operatorname{lnEXPSTU}$ & 1.000 & & & & & & & & & & \\
\hline lnPrimary & -0.944 & 1.000 & & & & & & & & & \\
\hline lnSecondary & 0.935 & -0.888 & 1.000 & & & & & & & & \\
\hline lnTertiary & -0.261 & 0.242 & -0.073 & 1.000 & & & & & & & \\
\hline $\operatorname{lnUNEM}$ & 0.474 & -0.379 & 0.643 & -0.016 & 1.000 & & & & & & \\
\hline $\operatorname{lnWORK}$ & -0.812 & 0.876 & -0.649 & 0.290 & 0.078 & 1.000 & & & & & \\
\hline $\operatorname{lnOPEN}$ & 0.792 & -0.842 & 0.672 & -0.204 & -0.089 & -0.966 & 1.000 & & & & \\
\hline $\operatorname{lnFDI}$ & 0.717 & -0.814 & 0.568 & -0.225 & -0.196 & -0.966 & 0.944 & 1.000 & & & \\
\hline $\ln R D$ & 0.928 & -0.963 & 0.822 & -0.355 & 0.384 & -0.856 & 0.782 & 0.781 & 1.000 & & \\
\hline INF & -0.292 & 0.272 & -0.189 & 0.425 & -0.334 & 0.160 & 0.052 & -0.062 & -0.361 & 1.000 & \\
\hline $\ln K$ & -0.083 & 0.251 & 0.158 & 0.234 & 0.742 & 0.637 & -0.568 & -0.686 & -0.274 & 0.012 & 1.000 \\
\hline
\end{tabular}

Note: To simplify the results, we highlight the strength of the correlation in color for the absolute values of the correlation ranging between 0 - and 0.30 (green), between 0.31 - and 0.80 (yellow), and between 0.81 - and 1.0 (orange) which indicate the weak, moderate, and strong correlation, respectively.

\section{References}

1. Volchik, V.; Oganesyan, A.; Olejarz, T. Higher Education as a Factor of Socio-Economic Performance and Development. J. Int. Stud. 2018, 11, 326-340. [CrossRef] [PubMed]

2. Holland, D.; Liadze, I.; Rienzo, C.; Wilkinson, D. The Relationship between Graduates and Economic Growth across Countries; BIS Research Paper 110; Department for Business Innovation \& Skills: London, UK, 2013. 
3. Gyimah-Brempong, K.; Paddison, O.; Mitiku, W. Higher Education and Economic Growth in Africa. J. Dev. Stud. 2006, 42, 509-529. [CrossRef]

4. Holmes, C. Has the Expansion of Higher Education Led to Greater Economic Growth? Natl. Inst. Econ. Rev. 2013, 224, R29-R47. [CrossRef]

5. Valero, A.; Van Reenen, J. The Economic Impact of Universities: Evidence from across the Globe. Econ. Educ. Rev. 2019, 68, 53-67. [CrossRef]

6. Szarowská, I. Does Public R\&D Expenditure Matter for Economic Growth? J. Int. Stud. 2017, 10, 90-103.

7. Carrillo, M. Measuring and Ranking R\&D Performance at the Country Level. Econ. Sociol. 2019, 12, 100-114.

8. Keller, K.R. Investment in Primary, Secondary, and Higher Education and the Effects on Economic Growth. Contemp. Econ. Policy 2006, 24, 18-34. [CrossRef]

9. Bilan, Y.; Mishchuk, H.; Roshchyk, I.; Kmecova, I. An Analysis of Intellecutal Potential and its Impact on the Social and Economic Development of European Countries. J. Compet. 2020, 12, 22. [CrossRef]

10. Ganegodage, K.R.; Rambaldi, A.N. The Impact of Education Investment on Sri Lankan Economic Growth. Econ. Educ. Rev. 2011, 30, 1491-1502. [CrossRef]

11. Mercan, M.; Sezer, S. The Effect of Education Expenditure on Economic Growth: The Case of Turkey. Procedia Soc. Behav. Sci. 2014, 109, 925-930. [CrossRef]

12. Jin, L.; Jin, J.C. Internet Education and Economic Growth: Evidence from Cross-Country Regressions. Economies 2014, 2, 78-94. [CrossRef]

13. Liao, L.; Du, M.; Wang, B.; Yu, Y. The Impact of Educational Investment on Sustainable Economic Growth in Guangdong, China: A Cointegration and Causality Analysis. Sustainability 2019, 11, 766. [CrossRef]

14. Maneejuk, P.; Yamaka, W.; Sriboonchitta, S. Does the Kuznets Curve Exist in Thailand? A Two Decades' Perspective (1993-2015). Ann. Oper. Res. 2019, 1-32. [CrossRef]

15. Schultz, T.W. Investment in Human Capital. Am. Econ. Rev. 1961, 51, 1-17.

16. Mincer, J. Schooling, Experience, and Earnings; Columbia University Press: New York, NY, USA, 1974.

17. Solow, R.M. Technical Change and the Aggregate Production Function. Rev. Econ. Stat. 1957, 39, 312-320. [CrossRef]

18. Lucas, R.E., Jr. On the Mechanics of Economic Development. J. Monet. Econ. 1988, 22, 3-42. [CrossRef]

19. Romer, P. Endogenous Technological Change. J. Political Econ. 1990, 99, S71-S102. [CrossRef]

20. Mankiw, N.G.; Romer, D.; Weil, D.N. A Contribution to the Empirics of Economic Growth. Q. J. Econ. 1992, 107, 407-437. [CrossRef]

21. Barro, R.J. Economic Growth in a Cross Section of Countries. Q. J. Econ. 1991, 106, 407-443. [CrossRef]

22. Habibi, F.; Zabardast, M.A. Digitalization, Education and Economic Growth: A Comparative Analysis of Middle East and OECD Countries. Technol. Soc. 2020, 63, 101370. [CrossRef]

23. Saviotti, P.P.; Pyka, A.; Jun, B. Education, Structural Change and Economic Development. Struct. Chang. Econ. Dyn. 2016, 38, 55-68. [CrossRef]

24. Hanushek, E.A.; Woessmann, L. How Much Do Educational Outcomes Matter in OECD Countries? Econ. Policy 2011, 26, 427-491. [CrossRef]

25. Cohen, D.; Soto, M. Growth and Human Capital: Good Data, Good Results. J. Econ. Growth 2007, 12, 51-76. [CrossRef]

26. Barro, R.J.; Lee, J.W. A New Data Set of Educational Attainment in the World, 1950-2010. J. Dev. Econ. 2013, 104, 184-198. [CrossRef]

27. Wobst, P.H.S.A. The Impact of Increased School Enrollment on Economic Growth in Tanzania. Afr. Dev. Rev. 2005, 17, 274-301. [CrossRef]

28. Lin, T.C. Education, Technical Progress, and Economic Growth: The Case of Taiwan. Econ. Educ. Rev. 2003, 22, 213-220. [CrossRef]

29. Lin, T.C. The Role of Higher Education in Economic Development: An Empirical Study of Taiwan Case. J. Asian Econ. 2004, 15, 355-371. [CrossRef]

30. Achim, M.V. The New Economy-Asking for New Education Approaches. Evidence for Romania and Other Post-communist European Countries. Procedia Econ. Finance 2015, 32, 1199-1208. [CrossRef]

31. Zhu, X. The Effect of Education on Economic Growth-An Empirical Research Based on the EBA Model. J. Interdiscip. Math. 2014, 17, 67-79. [CrossRef]

32. Abu, B.N.; Haseeb, M.; Azam, M. The Nexus between Education and Economic Growth in Malaysia: Cointegration and Toda-Yamamoto Causality Approach. Actual Probl. Econ. 2014, 162, 131-141.

33. Sylwester, K. Income inequality, education expenditures, and growth. J. Dev. Econ. 2000, 63, 379-398. [CrossRef]

34. Krueger, A.B.; Lindahl, M. Education for Growth: Why and for Whom? J. Econ. Lit. 2001, 39, 1101-1136. [CrossRef]

35. Jalil, A.; Idrees, M. Modeling the Impact of Education on the Economic Growth: Evidence from Aggregated and Disaggregated Time Series Data of Pakistan. Econ. Model. 2013, 31, 383-388. [CrossRef]

36. Marquez-Ramos, L.; Mourelle, E. Education and Economic Growth: An Empirical Analysis of Nonlinearities. Appl. Econ. Anal. 2019, 27, 21-45. [CrossRef]

37. Hansen, B.E. Regression Kink with an Unknown Threshold. J. Bus. Econ. Stat. 2017, 35, 228-240. [CrossRef]

38. Pipitpojanakarn, V.; Maneejuk, P.; Yamaka, W.; Sriboonchitta, S. Expectile and Quantile Kink Regressions with Unknown Threshold. Adv. Sci. Lett. 2017, 23, 10743-10747. [CrossRef] 
39. Maneejuk, N.; Ratchakom, S.; Maneejuk, P.; Yamaka, W. Does the Environmental Kuznets Curve Exist? An International Study. Sustainability 2020, 12, 9117. [CrossRef]

40. Chen, Z.; Wu, Y. The Relationship between Education and Employment: A Theoretical Analysis and Empirical Test. Front. Econ. China 2007, 2, 187-211. [CrossRef]

41. Abdullah, A.J. Education and Economic Growth in Malaysia: The Issues of Education Data. Procedia Econ. Finance 2013, 7, 65-72. [CrossRef]

42. Birchler, K.; Michaelowa, K. Making Aid Work for Education in Developing Countries: An Analysis of Aid Effectiveness for Primary Education Coverage and Quality. Int. J. Educ. Dev. 2016, 48, 37-52. [CrossRef]

43. Mason, R.; Brown, W.G. Multicollinearity Problems and Ridge Regression in Sociological Models. Soc. Sci. Res. 1975, 4, 135-149. [CrossRef]

44. Hoerl, A.E.; Kennard, R.W. Ridge Regression: Biased Estimation for Nonorthogonal Problems. Technometrics 1970, 12, 55-67. [CrossRef]

45. Weissfeld, L.A.; Sereika, S.M. A Multicollinearity Diagnostic for Generalized Linear Models. Commun. Stat. Theory Methods 1991, 20, 1183-1198. [CrossRef]

46. Perez Melo, S.; Kibria, B.M. On Some Test Statistics for Testing the Regression Coefficients in Presence of Multicollinearity: A Simulation Study. Stats 2020, 3, 40-55. [CrossRef]

47. Zhang, J.; Cheng, L. Threshold Effect of Tourism Development on Economic Growth Following a Disaster Shock: Evidence from the Wenchuan Earthquake, PR China. Sustainability 2019, 11, 371. [CrossRef]

48. Engle, R.F.; Granger, C.W. Co-integration and Error Correction: Representation, Estimation, and Testing. Econom. J. Econom. Soc. 1987, 55, 251-276. [CrossRef]

49. Radu, M. The Impact of Political Determinants on Economic Growth in CEE Countries. Procedia Soc. Behav. Sci. 2015, 197, 1990-1996. [CrossRef]

50. Abbas, Q.; Nasir, Z.M. Endogenous Growth and Human Capital: A Comparative Study of Pakistan and Sri Lanka. Pak. Dev. Rev. 2001, 40, 987-1007. [CrossRef]

51. Pritchett, L. Where Has All the Education Gone? World Bank Econ. Rev. 2001, 15, 367-391. [CrossRef]

52. Aghion, P.; Howitt, P. Growth and Unemployment. Rev. Econ. Stud. 1994, 61, 477-494. [CrossRef]

53. Aghion, P.; Akcigit, U.; Deaton, A.; Roulet, A. Creative Destruction and Subjective Well-Being. Am. Econ. Rev. 2016, 106, 3869-3897. [CrossRef] [PubMed]

54. Fanati, L.; Manfredi, P. Population, Unemployment and Economic Growth Cycles: A Further Explanatory Perspective. Metroeconomica 2003, 54, 179-207. [CrossRef]

55. Vo, D.H.; Ho, C.M. Does Financial Integration Enhance Economic Growth in China? Economies 2020, 8, 65. [CrossRef]

56. Belloumi, M.; Alshehry, A.S. The Impact of International Trade on Sustainable Development in Saudi Arabia. Sustainability 2020, 12, 5421. [CrossRef]

57. Wang, Q. Fixed-Effect Panel Threshold Model Using Stata. Stata J. Promot. Commun. Stat. Stata 2015, 15, 121-134. [CrossRef]

58. Miao, K.; Li, K.; Su, L. Panel Threshold Models with Interactive Fixed Effects. J. Econ. 2020, 219, 137-170. [CrossRef] 